\title{
Education and Income in the Early Twentieth Century: Evidence from the Prairies
}

\section{Citation}

Goldin, Claudia and Lawrence F. Katz. Education and income in the early twentieth century: evidence from the prairies. 2000. Journal of Economic History 60(3): 782-818.

\section{Published Version}

http://dx.doi.org/10.1017/S0022050700000334

\section{Permanent link}

http://nrs.harvard.edu/urn-3:HUL.InstRepos:2766688

\section{Terms of Use}

This article was downloaded from Harvard University's DASH repository, and is made available under the terms and conditions applicable to Other Posted Material, as set forth at http:// nrs.harvard.edu/urn-3:HUL.InstRepos:dash.current.terms-of-use\#LAA

\section{Share Your Story}

The Harvard community has made this article openly available.

Please share how this access benefits you. Submit a story.

\section{Accessibility}




\section{Education and Income in the Early Twentieth Century: Evidence from the Prairies}

\section{Claudia Goldin and LawrEnce F. KatZ}

We present the first estimates of the returns to years of schooling before 1940 using a large sample of individuals (from the 1915 lowa State Census). The returns to a year of high school or college were substantial in 1915-about 11 percent for all males and in excess of 12 percent for young males. Education enabled individuals to enter lucrative white-collar jobs, but sizable educational wage differentials also existed within occupational groups. Returns were substantial even for those in farming. We find, using U.S. census data, that returns to education decreased between 1915 and 1940 and again during the 1940s.

$\mathrm{T}$ he distribution of earnings is substantially shaped by a race between technology and education. ${ }^{1}$ There are times when technology forges ahead and the wage structure widens. At other times, education makes great strides and the distribution narrows. The first few decades of the twentieth century witnessed both changes. America moved decisively ahead in education by putting the majority of its youth through high school, a feat no other country would match for many decades to come. At the same time, there was enormously growing demand for skilled workers in the office and on production jobs. ${ }^{2}$

A considerable amount is now known about the increase in education among Americans in the twentieth century. But we know far less about the stock of educated Americans, occupations by education, the pecuniary returns to education, and the role of formal schooling in advancing productivity during the first half of the twentieth century. In large measure, our ignorance owes to data deficiencies. The 1940 U.S. population census was the first to inquire about education and earnings. This article remedies some of

The Journal of Economic History, Vol 60. No. 3 (Sept. 2000). (O) The Economic History Association. All rights reserved. ISSN 0022-0507.

Claudia Goldin and Lawrence F. Katz are Professors, Department of Economics, Harvard University, Cambridge, MA 02138, and Research Associates, National Bureau of Economic Research. E-mail: cgoldin@harvard.edu and lkatz@harvard.edu.

The authors thank the Spencer Foundation (Grant No. 199600128) for providing the funds to collect the sample from the 1915 Iowa State Census and the National Science Foundation (Grant No. SBR9515216) for research support. We thank Alwyn Young, David Zimmerman, and two referees for this journal for helpful comments. This article has also benefited from seminars at Boston University, the University of Chicago, Harvard University, Iowa State University, NBER, and University of California, Berkeley.

1 The phrase the "race between technology and education" comes from Tinbergen, Income Differences.

${ }^{2}$ On international comparisons of educational attainment before 1940, see Goldin and Katz, "Why the United States." On the increase in the relative demand for skill, see Goldin and Katz, "Origins." 
these deficiencies by using a unique data source-the 1915 Iowa State Census. Together with the U.S. federal population censuses beginning with 1940, the 1915 Iowa State Census will allow us to say something concrete about the outcome of the "race" during the first half of the twentieth century. ${ }^{3}$

We present the first estimates of the returns to years of schooling before 1940 using a large sample of men and women employed in a variety of sectors and occupations. ${ }^{4}$ We find that the returns to a year of high school, and to a year of college, were substantial in 1915-about 11 percent for all males and in excess of 12 percent for young males. Part of the return to years of high school and college arose because more education allowed individuals to enter lucrative white-collar jobs. But we also find sizable educational wage differentials within the white- and blue-collar sectors. Of great importance for this largely farming state is that returns to education above the "common school" grades were substantial within the agricultural sector. Given the high overall rate of return to secondary schooling, it is no wonder that the "high school movement" took root in America around 1910, even in agricultural areas.

We begin with a description of the high school movement and why prairie states, such as Iowa, led most others in secondary education. Data deficiencies concerning the measurement of the returns to education and the human capital stock for the first half of the twentieth century are taken up next, and the unique features of the Iowa State Census of 1915 are discussed. We then use the Iowa data to assess educational stocks and flows and the returns to education in 1915. We evaluate the returns generally and for white- and blue-collar workers separately. Because Iowa was largely a farming state, we also assess the role of schooling in enhancing agricultural productivity. To put the findings from 1915 in perspective, we use the Integrated Public Use Microdata Samples (IPUMS) from the 1940, 1950, and 1960 U.S. population censuses to evaluate changes in the returns to education in the first half of the twentieth century. The comparison suggests that the return to a year of high school declined over time and thus that the "race" was won, at least for a while, by education.

\footnotetext{
${ }^{3}$ Goldin, "America's Graduation," presents evidence for the early-twentieth-century increase in education, known as the "high school movement." Goldin and Katz, "Returns," provides additional information on the "race" in terms of skill differentials within and between manual and white-collar occupations.

${ }^{4} \mathrm{By}$ the return to a year of schooling we mean the log earnings difference between a worker with $t+1$ years of schooling and one with $t$ years. Specifically we mean the coefficient on years of schooling in a $\log$ earnings regression with controls for potential labor-force experience and other covariates. We do not construct an "internal rate of return" to education, and thus returns for women will be overstated when their participation rates are low. We follow the tradition since Mincer, Schooling, of denoting such earnings differentials as the "returns to schooling." We are aware of the difficulties in providing a causal interpretation to earnings differences by years of schooling. See Card, "Causal Effect," on these issues.
} 


\section{THE HIGH SCHOOL MOVEMENT AND THE PRAIRIE STATES}

In 1900 just 6 percent of all 17-year olds in the United States graduated from secondary schools. By 1930, 30 percent did-35 percent outside the South. Public secondary schooling did not diffuse uniformly across America, even across the nonsouthern states. New England's states took an early lead but they were quickly surpassed by many in the West and in the central portion of the nation. (Those in the central section are known as the "prairie states.") In 1910, as the "high school movement" was just beginning, the secondary-school graduation rate among youth in New England was 16 percent, although it was 9 percent nationally and 11 percent in the states outside the South. ${ }^{5}$ In 1926 , however, when the national high school graduation rate was 26 percent and that in New England was 34 percent, the rate for the Pacific and prairie states exceeded 40 percent (see Figure 1). ${ }^{6}$ Not only did the prairie states lead in education early in the century, many of them remain educational leaders today. ${ }^{7}$

The prairie may appear to have been an unlikely place for an educational movement to sprout a century ago. The communities that then fostered progressive education are, even today, rural cross-roads and isolated towns. But on further consideration, it is more transparent why these places became educational leaders. The prairie states were wealthy farming areas during the first three decades of the twentieth century and wealth in land is more easily taxed than in its portable forms. Of the five highest states in per capita taxable wealth in 1912, three are in the West North Central (lowa was second, North Dakota third, and Nebraska fifth). Four of the six prairie states were among the top ten wealthiest, on a per capita basis, in $1922 .{ }^{8}$

The prairie states were populated by progressive farmers at a time when running a farm increasingly required knowledge of chemistry, botany, accounting, electricity, and other tools of modern science. Youths in these states could not have worked in industry, for there was scant manufacturing in these mainly commercial and agriculturally oriented communities. ${ }^{9}$ And

\footnotetext{
${ }^{5}$ By graduation rate, we mean the total number of secondary-school graduates (from public high schools, private high schools, and college preparatory departments) divided by the number of 17 -year olds.

${ }^{6}$ We define the prairie states to include those of the West North Central census division minus Missouri. Some of these states are better described as Great Plains states, but the state on which we focus (lowa) and the other more populous states of the region are prairie states. If we instead use a narrower definition and include only Iowa, Kansas, and Nebraska (all prairie states), the high school graduation rate for the prairie and the Pacific states would have been 46 percent in 1926.

${ }^{7}$ The top three states of an educational index for 1990 to 1996 are all in the West North Central: North Dakota, Iowa, and Minnesota, in that order. Six of the seven West North Central states are in the top twelve. The educational index combines measures of test scores and high school dropout rates. See Braatz and Putnam, "Families."

${ }^{8}$ See U.S. Department of Commerce, Statistical Abstract, 1925.

${ }^{9}$ In 1910 the share of employment in manufacturing was 9.1 percent in the prairie states $(10.5$ percent in Iowa), but 20.2 percent for all states and 26.8 percent for those outside the South and the West North Central (excluding Missouri). Source: 1910 IPUMS, all workers greater than or equal to 14 years old.
} 


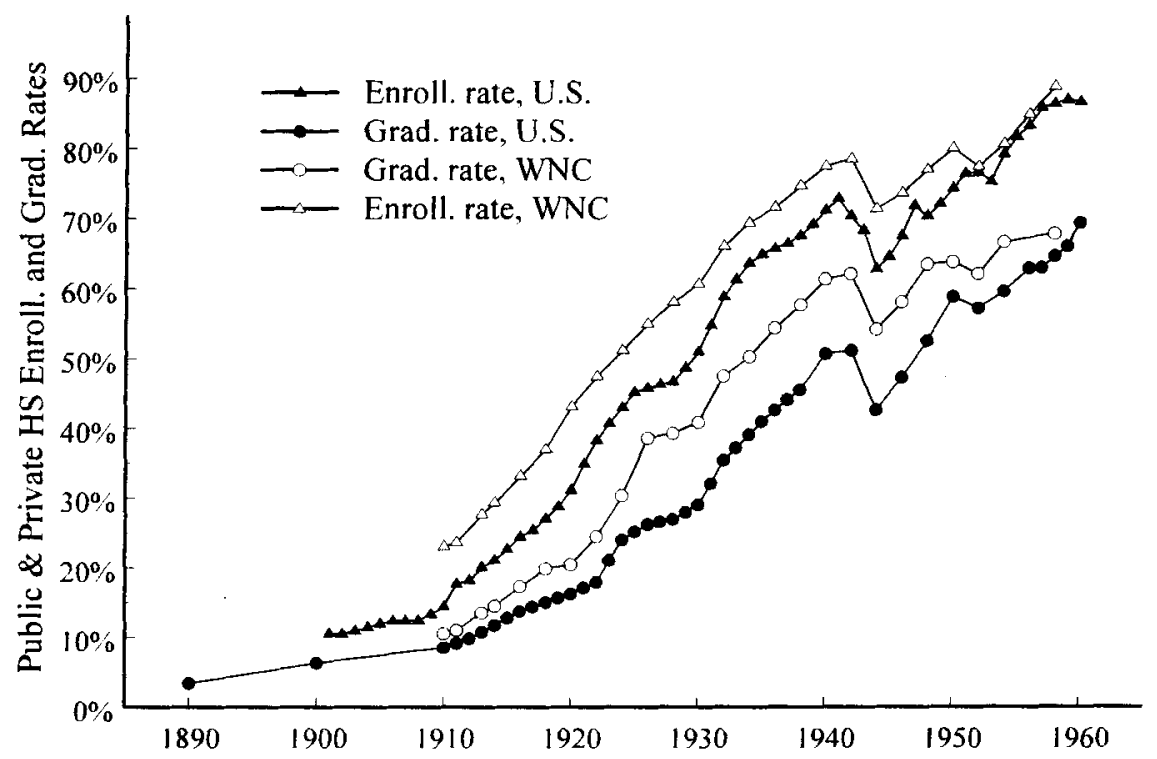

FIGURE 1

PUBLIC AND PRIVATE HIGH SCHOOL ENROLLMENT AND GRADUATION RATES: UNITED STATES AND THE WEST NORTH CENTRAL CENSUS DIVISION, 1890 TO 1960

Notes: The enrollment rate divides the number of students enrolled in high school (grades 9 through 12) by the number of 14- to 17-year olds. The graduation rate divides the number of high school graduates by the number of 17-year olds. High schools include public schools, private schools, and the preparatory departments of colleges and universities. The West North Central census division includes the states of Iowa, Kansas, Minnesota, Missouri, Nebraska, North Dakota, and South Dakota. In the text, the "prairie states" are defined as those of the West North Central minus Missouri.

Sources: U.S. Department of Education, 120 Years; and Goldin, "America's Graduation" and "Education Statistics."

although many farmers would have preferred that their children remain on the land, most knew it would prove impossible. The best they could do was to endow them with education to be mobile. The prairie state on which we will focus-Iowa-was, moreover, about as "urban" in 1915 as was the rest of the nation. Iowa was densely dotted with the "central places" of location theory, and these small towns were incubators of "social capital." 10

\footnotetext{
${ }^{10}$ By the usual definition of urban-incorporated areas with more than 2,500 persons--iowa was less urban than was the United States in 1910 (45.7 percent versus 30.6 percent). But Iowans had a much higher fraction of their residents living in incorporated places with fewer than 2,500 residents than did the rest of the United States. Including as urban in 1910 all residents of incorporated places makes the comparison 54.5 percent for the United States and 50.3 percent for Iowa For the U.S. data, see U.S. Bureau of the Census, Historical Statistics, series A 57-72; for the Iowa data, see State of Iowa, Census of Iowa, 1915. On the role of small towns in the diffusion of high schools, see Goldin and Katz, "Human Capital."
} 


\section{EVIDENCE ON SCHOOLING AND INCOME BEFORE 1950}

Information that could reveal education's role in enhancing productivity in the first half of the twentieth century has been difficult to obtain. Only with the 1940 U.S. population census was there a survey at the national level that asked years of education and earnings. ${ }^{11}$ Yet even the 1940 census omits considerable information on both variables.

As Americans made the transition from rural areas to cities and from farms to factories, American children made a related shift from the one-room "common school" to the graded grammar school. But the 1940 U.S. federal census asked about highest grade completed, not years in various types of schools. The information requested does not enable one to evaluate whether the transition from common to grammar schools, and then to high schools, made a difference over and above the increase in years of education.

The data on highest grade completed in the 1940 census, moreover, appear to contain various biases. Because many older Americans had attended common, not graded schools, "highest grade completed" was often translated as "years of school attended." Contemporaneous evidence on high school enrollments and graduates reveals that older Americans in the 1940 census greatly inflated their completion of the upper secondary-school grades. ${ }^{12}$

With regard to the earnings variable in the 1940 census, wage and salary information was requested, but income from self-employment was not. Thus the relationship between earnings and education cannot be studied for the 25 percent of the male labor force ( 25 to 64 years old) that was self-employed in 1939. The self-employed, moreover, included virtually all of the farm population as well as a disproportionate number of the highly educated among the nonfarm group. ${ }^{13}$

Even if the estimates of educational returns from the 1940 census had no measurement problems, the year is too late in the nation's history to explain why the "high school movement" occurred. By 1940 half of all youths across the United States were high school graduates, and graduation rates exceeded 65 percent in many states, including those in the New England, Pacific, and West North Central regions. Thus many issues regarding education and economic growth cannot be addressed with the 1940 census either because the data are not available or because the time period is after the fact.

\footnotetext{
${ }^{11}$ Ever since 1850, the U.S. population census inquired about school attendance during the year. It is possible that the U.S. Bureau of the Census believed that a question on highest grade completed would be ambiguous since large numbers of individuals had attended rural or European ungraded (common) schools. For them, years of school, not grade, would have been the relevant metric.

${ }^{12}$ See Goldin, "America's Graduation," regarding the overstatement of secondary-school graduation in the 1940 census. It appears that many of the older cohorts inflated their high school graduation rate (that is, whether they had attended 12 or more years of school), some by as much as 1.5 to 2 times the actual rate. The inflation may be due to the confusion between years of school and highest grade completed.

${ }^{13}$ Individuals are considered self-employed if they are employers or "working on own account." Among (male) farmers and farm managers, 98 percent are listed as self-employed. Source: 1940 IPUMS.
} 
Several datasets for the period before 1940 contain information on education and income. ${ }^{14}$ But only one is of substantial size and has adequate breadth of coverage regarding related variables, such as age, occupation, sex, and family background. That dataset is derived from the Iowa State Census of 1915. Almost all states since the early nineteenth century, or from the time they achieved statehood, surveyed their populations at ten-year intervals, often mid-decade between two U.S. population censuses.$^{15}$ Both Iowa and South Dakota, in their respective censuses of 1915, inquired of their residents' educational attainment. It was the first time a state had asked such a question in its census. Although lowa retained the education question in its 1925 census, that on income was dropped.

\section{THE IOWA STATE CENSUS OF 1915}

The 1915 Iowa State Census is a 100 percent sample that was taken by county assessors on a household-to-household basis. An index card was filled out for each individual containing information on age, sex, race, school attendance, educational attainment (by type of school, viz., common, grammar, high school, college), occupation, income in 1914, value of property, incumbrance on home or farm, church affiliation, and years in the United States and in Iowa, among other items (see a facsimile of the form in the Data Appendix). Although the census did not ask relationship to others in the household, information on the cards allows the reconstruction of nuclear family units for those living in the same household.

Using microfilm copies of the cards, we have collected a cluster sample of almost 60,000 individuals ( 1 in 40 sample) from three cities (Davenport, Des Moines, and Dubuque) and ten counties that did not contain a city with more than 25,000 people. We term this sample "Iowa 1915"; that from the three cities is called the "urban" sample and the ten counties' data comprise the "rural" sample, although the counties contained urban places of various sizes. ${ }^{16}$

Why the state of Iowa undertook a census that was 25 years ahead of its time is not fully clear. One possibility is that lowans wanted to broadcast to the rest of the nation that they were highly educated, cosmopolitan people, not backward, rural "hayseeds." The published census proclaimed

\footnotetext{
${ }^{14}$ See, for example, Gorseline, Effect, which contains a sample of brothers. Goldin and Katz, "Decline" and "Returns," present a wage series, from 1890 to 1960, for occupations that had differing schooling qualifications. The 1934/36 Consumer Expenditure Survey has recently been made available in electronic form. The survey contains data on education and earnings for about 14,000 families, although mainly from the central portion of the wage structure.

${ }^{15}$ On state censuses, see Dubester, State Censuses.

${ }^{16}$ Our 1915 Iowa State Census sample is large, representative of the state, and derived from a true population census. See the Data Appendix for information on our lowa sample, including the use of sampling weights. Others who have drawn samples from the 1915 Iowa State Census include Jensen and Friedberger, "Education"; and Smith, "Number."
} 
that: "The enumeration for the first time included an inquiry into the extent of education ... and this happily confirms the claim of very high rank for Iowa in educational standing." ${ }^{17}$ Another possibility, which we document below, is that lowans were 25 years ahead of the nation in educational attainment.

Even though high schools had already spread across much of Iowa by 1915, many adult Iowans had been educated at times when, and in places where, schooling was limited to that garnered in the rural common schools. ${ }^{18}$ Among native-born Iowans older than 20 years in 1915, 47 percent had been educated in the common schools only. Furthermore, 69 percent of Iowa's foreign born older than 20 years, and 73 percent of those who arrived in the United States after age 18, had received all of their education in common schools, largely European ones. ${ }^{19}$ Almost all adult Iowans had been educated before 1913 when the state passed a "free tuition" law, which made the payment of secondary-school tuition the fiscal responsibility of the youth's school district. ${ }^{20}$ Therefore adult Iowans in 1915 who had attended secondary school either had lived in districts maintaining a high school or had paid tuition to another district. Although the majority (51 percent) of adult Iowans were educated only in common schools, a small group attended universities and colleges, many of which had had a presence in the state ever since the mid-nineteenth century. ${ }^{21}$

The 1915 Iowa State Census, therefore, surveyed a population that had been educated across a wide variety of educational institutions--the one-room common schools of rural America and Europe, the city and town grammar and secondary schools, and the college and university. In recognition of this diversity, the census inquired as to the type of institution in which the individual was educated - common, grammar, high school, and college - and the years in each. We are, thus, able to explore the role of educational institutions that disappeared as graded and secondary schools replaced them.

${ }^{17}$ State of Iowa, Census of Iowa, 1915, preface, n.p.

${ }^{18}$ In 1890 there were 140 secondary schools in lowa, but in 1914 there were 805 , of which 490 were approved. Approval meant that the state universities would accept graduates without examination (Johnson, "State"). There were 928 independent city, town, and village corporations among the 99 counties in Iowa. Since there were 58 cities and towns with populations exceeding 3,000 and 63 with populations between 1,500 and 3,000 , most of these corporations had populations under 1,500. That is, by 1914 most of the incorporated cities, towns, and villages had their own high school, although not necessary an approved one. Children in the open country, however, may still have been far removed from a secondary school. Data are from the State of Iowa, Biennial Reports.

${ }^{19}$ The native-born and foreign-born calculations use the Iowa 1915 sample and exclude those who attended no school ( 1 percent of the native born and 3 percent of the foreign born). Of those older than 20 years in 1915, 18 percent were foreign born.

${ }^{20}$ According to Iowa school reports, the law passed the thirty-fourth General Assembly in 1913. For many years after, about one-quarter of local revenue for secondary schools came from tuition payments of neighboring districts.

21 There were 19 colleges and universities spread across Iowa in 1897, only 4 of which were founded after 1880 (see Goldin and Katz, "Shaping"). 
In rural communities having no secondary school, pupils often went to common school for more than eight years. ${ }^{22}$ The 1915 census allows an assessment of whether such education had the same impact on earnings as did years in the more modern high schools. The question takes on some importance when considering that the apparent overstatement of high school graduation in the 1940 census could have resulted from a recoding of common school years. Similarly, many youths desiring a college or university education attended the preparatory departments of those institutions, particularly if no high school existed in their locale or if the school could not adequately prepare them for college entrance. Such individuals may have attended eight years of common or grammar school and then, perhaps, six or more years of "college." The 1915 Iowa census is, to our knowledge, the only U.S. survey that allows an examination of the differential effectiveness of years in a wide range of precollege institutions.

\section{EDUCATIONAL STOCKS AND FLOWS}

When Iowans proclaimed in 1915 that they attained a "very high rank ... in educational standing," they could not have known just how high, since only one other state (and a neighboring one at that) had surveyed their residents on the question. Iowans were aware that they were more literate than those in other states, because the U.S. population census inquired of literacy ever since 1850. Iowans should also have known that they had achieved an admirable school attendance rate-second in the nation in 1900 and 1910 for the U.S. census had inquired of school attendance since $1850 .{ }^{23}$

But Iowans could not have known that the school attendance rate of their 5 to 19-year olds-which was 73 percent in 1915-was almost equal to that achieved in the nation by $1940 .{ }^{24}$ Thus, youth in 1915 Iowa were, on average, about a quarter of a century ahead of other American children in their

\footnotetext{
${ }^{22}$ County school superintendents administered an eighth grade examination twice yearly to common school students. Passage of the examination allowed them to advance to secondary school. Common schools in areas distant from a town high school occasionally added one or two extra years beyond that required for the eighth grade examination. The lowa Biennial for 1903 noted that a two-year high school course existed "for advanced rural schools and the small graded schools" (p. xxi). The extended course was more usual before the advent of the "free tuition" law of 1913. After passage of the law, the state tightened controls on what constituted a high school course since districts not containing a secondary school were liable for tuition payments.

${ }^{23}$ According to the 1910 U.S. federal population census, Iowa had the lowest rate of illiteracy in the nation among its adult population. It ranked second to Vermont in 1910, and to Nebraska in 1900, in terms of the school attendance of its 5- to 20-year olds (U.S. Bureau of the Census, Thirteenth Census, Vol. 1, tables 19, 29).

${ }^{24}$ In 1940 the school enrollment rate of 5 to 19-year olds in the United States was 0.748 (U.S. Department of Education, 120 Years, table 2). The school attendance rate in 1915 for 5 to 19-year olds in lowa was 0.726 (Iowa 1915 sample). Because attendance rates are generally lower than enrollment rates, the 1915 Iowa attendance level may have been even higher than the enrollment rate for the entire country in 1940 .
} 
TABLE 1

FORMAL SCHOOLING INDICATORS IN 1915 IOWA AND 1940 UNITED STATES: BY SEX FOR 25- TO 59-YEAR OLDS

\begin{tabular}{|c|c|c|c|c|}
\hline & \multicolumn{2}{|c|}{ Males, 25- to 59-Years Old } & \multicolumn{2}{|c|}{$\begin{array}{c}\text { Females, 25- to 59-Years } \\
\text { Old }\end{array}$} \\
\hline & 1915 Iowa & $\begin{array}{l}1940 \text { United } \\
\text { States }\end{array}$ & 1915 Iowa & $\begin{array}{l}1940 \text { United } \\
\text { States }\end{array}$ \\
\hline Mean highest grade completed (1) & 8.40 & & 8.68 & \\
\hline Mean highest grade completed (2) & 8.56 & 8.60 & 8.86 & 8.86 \\
\hline Average years of education & 8.61 & & 8.98 & \\
\hline Fraction with less than 8 years & 0.235 & 0.311 & 0.185 & 0.278 \\
\hline Fraction with some high school (1) & 0.233 & 0.410 & 0.290 & 0.462 \\
\hline Fraction with some high school (2) & 0.379 & & 0.446 & \\
\hline Fraction graduating high school (1) & 0.152 & 0.248 & 0.179 & 0.287 \\
\hline Fraction graduating high school (2) & 0.156 & & 0.184 & \\
\hline
\end{tabular}

Notes and Sources:

1915: Iowa 1915 sample (see Data Appendix). The assessors asked the "extent of education" in years, in common school, grammar school, high school, and college listed separately.

1940: IPUMS. The enumerators were asked to inquire "what is the highest grade of school completed." The instruction to the enumerators explains: "This question refers only to the education obtained in public, private, or parochial schools, colleges, or universities. Education obtained at vocational schools is not to be considered, unless such school or college was part of the regular school system.... Enter [college 1 through 5] whether or not the person was graduated from high school. For persons whose highest grade completed was in a junior high school, it will be necessary to ascertain the equivalent in terms of ... grades." (ICPSR, Census of Population, 1940, 6.40-6.41). The highest grade of school cannot exceed 17.

Mean highest grade completed [1915]: reconstructs the 1915 data to approximate the 1940 instructions to enumerators. In agreement with the 1940 census, the highest grade is truncated at seventeen. Consistent with the instructions to enumerators, if an individual attended eight years of grammar school and four years of college but no high school, for example, the individual received 16 years of schooling, rather than 12. For version (1) no individual in 1915 is given years of education beyond eight for the sum of common and grammar school years. For version (2) the cutoff is nine years.

Average years of education: the sum of years of schooling in the various school categories with a truncation at 17 years.

Fraction with some high school [1915]: fraction with highest grade completed equal to at least nine. Version (1) and (2) differ in the same manner as for mean highest grade completed [1915].

Fraction with some high school [1940]: fraction with highest grade completed equal to at least nine.

Fraction graduating high school [1915]: fraction with highest grade completed equal to at least twelve. Version (1) and (2) differ in the same manner as for mean highest grade completed [1915].

Fraction graduating high school [1940]: fraction with highest grade completed equal to at least 12.

school attendance. Iowans would also have been unaware that the average educational attainment of their adult population would not be equaled in the entire United States until about 1940.

To demonstrate this point, we compare in Table 1 the educational attainment of 25- to 59-year olds in 1915 Iowa with that of the same age group in the United States in 1940. By the standard of mean highest grade completed (or average years of education), Iowans in 1915 had the same educational attainment as did the average American in $1940 .{ }^{25}$ The proportion who were

\footnotetext{
${ }^{25}$ The 1940 U.S. population census asked individuals their highest grade attended, but many gave their total years of education and the census enumerators were instructed to translate years into grades.
} 
high school graduates was greater in the United States in 1940 than in Iowa in 1915 , but the 1940 census overstates the high school graduation rate. ${ }^{26}$ Probably closer to the truth is that the fraction attending some secondary school in 1915 Iowa, using the Table 1 version 2 estimate, is not much lower than that for the entire United States in 1940. The fraction with fewer than eight years of formal schooling is, however, lower in Iowa in 1915 than in the United States in 1940, possibly because the Iowa census requested "years of schooling" and the U.S. census inquired of "grades."27

Although many adult Iowans were educated entirely in common schools, about half of their total years of education were garnered in graded schools (see Table 2). Women had more years of schooling than did men yet fewer years above the secondary level, a finding familiar from other studies. ${ }^{28}$ More surprising is that Iowans living in the larger cities had total years of education about equal to that for those living in small towns and rural places. Thus a high level of basic education was almost uniformly distributed across Iowa. Some differences did matter. Those born in Iowa had the most schooling - a bit more than nine years, whereas those educated abroad had the least-barely exceeding seven.

The points these data make are clear. Iowa in 1915 not only had an exceptional educational system for its youth, but it was also the home of an adult population that was about 25 years ahead of its time in formal schooling.

\section{SCHOOLING, INCOME, AND OCCUPATIONS: THE PREMIUM TO EDUCATION IN 1915}

There are several reasons to believe that structural changes in the economy in the late nineteenth and early twentieth centuries increased the relative demand for educated workers. The growth of big business, as described by Alfred Chandler, increased the demand for managers. ${ }^{29}$ Compared with

We have, for 1915, years in various types of schools, and thus have more complete information concerning years and grades than exists for the 1940 census. We offer, in Table 1, three summary statistics for educational attainment (see notes to Table 1). The choice will depend on what was actually measured in 1940-years or grades. All our tabulations from the 1940 population census use the sampling (person) weights from the 1940 IPUMS.

${ }^{26}$ The 1915 Iowa census data on high school attendance are in almost perfect agreement with contemporaneous administrative records on enrollment. The Iowa high school attendance rate for 1914, derived from the 1915 lowa State Census, is 0.3148; the enrollment rate from administrative records, using 14- to 17year olds as the reference group, is 0.3152 . In 1914, the high school enrollment rate for the entire United States was 0.240 , and it was 0.283 in the non-South. See Goldin, "America's Graduation," on the overstatement of high school graduation in the 1940 census and for the administrative data sources.

${ }^{27}$ To judge the comparability of the education data in 1915 and 1940, we have tracked a cohort of males born in Iowa between 1875 and 1890 . The concordance between the two series is extremely close once the 1915 educational data are adjusted to be consistent with the instructions to the enumerators in 1940, see the working paper version of this article, Goldin and Katz, "Education," table 2.

${ }^{28}$ See, for example, Tyack and Hansot, Learning Together.

${ }^{29}$ Chandler, Visible Hand. 
TABLE 2

YEARS OF SCHOOLING AND BY TYPE OF INSTITUTION, IOWA 1915

\begin{tabular}{lccccccc}
\hline & \multicolumn{3}{c}{ Years of Schooling by Type of Institution } & & \\
\cline { 2 - 5 } $\begin{array}{l}\text { Population of 25- } \\
\text { to 59-Year Olds }\end{array}$ & $\begin{array}{c}\text { Common } \\
\text { School }\end{array}$ & $\begin{array}{c}\text { Grammar } \\
\text { School }\end{array}$ & $\begin{array}{c}\text { High } \\
\text { School }\end{array}$ & College & Total & $\begin{array}{c}\text { Total, } \\
\text { Truncated }\end{array}$ \\
\hline Entire sample & 4.75 & 3.07 & 0.75 & 0.24 & 8.81 & 8.56 \\
$\quad$ Males & 4.82 & 2.89 & 0.64 & 0.28 & 8.63 & 8.40 \\
Females & 4.67 & 3.26 & 0.87 & 0.19 & 8.99 & 8.74 \\
Native-born & 4.69 & 3.27 & 0.85 & 0.26 & 9.06 & 8.80 \\
Iowa-born & 4.78 & 3.26 & 0.87 & 0.26 & 9.17 & 8.89 \\
Foreign-born & 5.05 & 2.05 & 0.25 & 0.12 & 7.47 & 7.36 \\
$\quad$ Male & 5.07 & 1.96 & 0.28 & 0.18 & 7.49 & 7.38 \\
$\quad$ Female & 5.02 & 2.18 & 0.21 & 0.04 & 7.45 & 7.34 \\
$\quad$ Arrived & 5.14 & 1.83 & 0.24 & 0.12 & 7.33 & 7.26 \\
$\quad>19$ years & & & & & & \\
Urban sample & 1.76 & 5.98 & 0.81 & 0.29 & 8.84 & 8.74 \\
Rural sample & 5.78 & 2.07 & 0.73 & 0.22 & 8.80 & 8.50 \\
\hline
\end{tabular}

Notes: "Years of schooling by type of institution" gives years in common, grammar, high school, or college respectively in each column. "Total" sums the years in each. "Total Truncated" sums the years in each but truncates the sum of common and grammar school at nine years and high school at four years. "Arrived $>19$ years" means that the individual came to the United States at age 20 or more. See the text or the Data Appendix for definitions of the "urban" and "rural" samples.

Source: Iowa 1915 sample (see the Data Appendix).

businesses in other industrial countries, American large-scale manufacturing was distinctive in its heavy reliance on skilled managers for decision making rather than shop-floor craftsmen. Offices expanded as modern accounting, marketing, and sales practices swept business around 1900 and increased the demand for clerical and sales workers. In 1900, as the era of big business was emerging, there were 13 production workers for each white-collar employee in manufacturing, but in 1909 there were six..$^{30}$ For the economy as a whole, the share of clerical workers in the nonagricultural workforce grew from 4.8 percent in 1900 to 11.0 percent in 1920 , and most of the growth occurred in the manufacturing sector. ${ }^{31}$ In fact, the relative demand for white-collar workers in manufacturing grew from 1890 to 1929 at a rate nearly as high as that reached from 1959 to 1989 , a period of rapid growth in the demand for skills. ${ }^{32}$ The expansion of large retail sales establishments and in the banking and insurance sectors further increased the relative demand for white-collar workers. Various vocations, such as those of accoun-

\footnotetext{
${ }^{30}$ On the comparison between U.S. and British management techniques, see Lazonick, Competitive Advantage. The 1900 and 1909 U.S. Census of Manufactures report proprietors and firm members, salaried officers, and superintendents, managers, clerks, and salesmen as an aggregate for the U.S. totals. We divide the number of all other employees by that aggregate, after subtracting the "hand trades," (for example, carpenters) from the 1900 figures. Sources: U.S. Census Office, Twelfth Census, 1900; U.S. Bureau of the Census, Thirteenth Census, 1910. Vol. 8.

${ }^{31}$ Rotella, From Home.

${ }^{32}$ Goldin and Katz, "Origins."
} 
tant, architect, and lawyer, were professionalized in the period around 1910, and the greater use by industry of scientific methods increased the need for chemists, engineers, and other science-related personnel.

The facts concerning the rising demand for white-collar workers, professionals, and skilled production workers beginning in the 1890 s seem clear. But how these shifting labor requirements were translated into an increased demand for educated workers depends on educational requirements for various occupations. These requirements have remained somewhat of a mystery for the pre-1940 period. In previous work we used job descriptions for the 1910s and 1920s to construct a group of white-collar occupations that required graduation from, or some years of, high school. In later work we used job descriptions for a host of blue-collar jobs to show that many, particularly those in high-tech industries, began to require and reward more formal schooling in the 1910 s and $1920 \mathrm{~s} .{ }^{33}$ With the Iowa State Census we can now directly observe the occupations of the more highly educated in 1915.

Table $3 \mathrm{~A}$ summarizes the educational distribution of workers by major occupation group. Although over 70 percent of those employed in 1915 Iowa (20- to 64-years old) had no more than a common or grammar school education, the vast majority of white-collar workers had high school or college education in 1915. The table reveals large differences in average schooling levels between ordinary white-collar workers and blue-collar workers.

We also examine in Table 3B, the occupations in which workers with different levels of education were employed in lowa in 1915. The vast majority of high school graduates and those who attended college were employed in white-collar occupations. For women (20- to 34-years old) with more than 12 years of schooling, only 5 percent were not white-collar workers, whereas among those with only common or elementary school 66 percent were not white-collar workers. For young men with more than 12 years of schooling 36 percent were not white-collar workers, whereas about 91 percent were not white-collar workers in the lowest education group listed. Women with some high school in 1915 were mainly clerical workers; among those having more than high school, about 60 percent were teachers. More educated men were professionals, managers, salesmen, and office workers.

We can infer, from the evidence just presented, that structural changes in the economy around 1900 increased the relative demand for workers with a high school education. Even though we do not have direct evidence that the high school movement began because of an increase in educational returns, we can estimate returns in 1914 at the start of the high school movement in an educational leader-Iowa.

\footnotetext{
${ }^{33}$ For the earlier work, see Goldin and Katz, "Decline." For the later work, see Goldin and Katz, "Origins."
} 
TABLE $3 \mathrm{~A}$

OCCUPATIONS AND EDUCATION, IOWA 1915: EDUCATIONAL DISTRIBUTIONS

(PERCENTAGE) BY OCCUPATION, MALES AND FEMALES 20- TO 64-YEARS OLD

\begin{tabular}{lcccrr}
\hline & $\begin{array}{c}\text { Common or } \\
\text { Grammar } \\
\text { School }\end{array}$ & $\begin{array}{c}\text { Some High } \\
\text { School }\end{array}$ & $\begin{array}{c}\text { High School } \\
\text { Graduate }\end{array}$ & $\begin{array}{r}\text { Some Col- } \\
\text { lege Plus }\end{array}$ & $\begin{array}{r}\text { Mean } \\
\text { Years }\end{array}$ \\
\hline All employed & 71.9 & 10.0 & 7.6 & 10.5 & 8.63 \\
Blue collar, service & 83.3 & 8.8 & 4.5 & 3.4 & 7.80 \\
$\quad$ Craft & 76.8 & 10.2 & 7.7 & 5.3 & 8.32 \\
White collar & 37.0 & 15.2 & 19.1 & 28.8 & 10.80 \\
$\quad$ Professional & 15.1 & 12.1 & 16.0 & 56.9 & 13.00 \\
Managers, proprietors & 55.2 & 13.6 & 14.1 & 17.1 & 9.62 \\
Clerical, sales & 40.2 & 17.9 & 23.5 & 18.5 & 10.29 \\
Farmers & 87.0 & 7.0 & 1.7 & 4.3 & 7.82 \\
\hline
\end{tabular}

TABLE 3B

OCCUPATIONS AND EDUCATION, IOWA 1915: OCCUPATIONAL DISTRIBUTIONS (PERCENTAGE) BY SCHOOLING, SEX, AND AGE

\begin{tabular}{|c|c|c|c|c|c|c|}
\hline \multirow[b]{2}{*}{ Schooling Level } & \multicolumn{3}{|c|}{ 20- to 64-Years Old } & \multicolumn{3}{|c|}{ 20- to 34-Years Old } \\
\hline & $\begin{array}{l}\text { White } \\
\text { Collar }\end{array}$ & $\begin{array}{l}\text { Blue Collar } \\
\text { and Service }\end{array}$ & Farmer & $\begin{array}{l}\text { White } \\
\text { Collar }\end{array}$ & $\begin{array}{l}\text { Blue Collar } \\
\text { and Service }\end{array}$ & Farmer \\
\hline \multicolumn{7}{|l|}{ Males } \\
\hline Common or grammar school & 12.2 & 49.8 & 38.0 & 9.3 & 57.3 & 33.4 \\
\hline Some high school & 33.2 & 41.1 & 25.6 & 29.1 & 47.3 & 23.6 \\
\hline High school graduate & 58.3 & 32.0 & 9.7 & 57.1 & 33.6 & 9.3 \\
\hline Some college plus & 67.4 & 16.6 & 5.9 & 63.8 & 20.8 & 15.4 \\
\hline \multicolumn{7}{|l|}{ Females } \\
\hline Common or grammar school & 29.1 & 61.1 & 9.8 & 33.8 & 62.8 & 3.3 \\
\hline Some high school & 66.2 & 30.9 & 2.9 & 73.6 & 23.7 & 2.7 \\
\hline High school graduate & 84.7 & 14.9 & 0.4 & 87.4 & 12.1 & 0.5 \\
\hline Some college plus & 92.0 & 7.6 & 0.4 & 94.9 & 4.7 & 0.5 \\
\hline
\end{tabular}

Notes: Only those with positive occupational earnings for 1914 and legibly written occupations are used. Blue-collar occupations include those in craft, operative, service, and laborer occupations (codes 300 to 988 using the 1940 occupational classification). White-collar occupations include those in professional, semiprofessional, managerial (excluding farming), clerical, and sales occupations (codes I to 45 , and 100 to 299 using the 1940 occupational classification). Schooling level is based on highest grade completed using the version (1) definition of Table 1. Education categories represent the highest grade, or year in a type of school, completed.

Source: Iowa 1915 sample (see the Data Appendix).

\section{Pecuniary Returns to Education}

We assess, in Table 4, the returns to schooling for males 18- to 65-years old and, in Table 5, for males and unmarried females 18- to 34-years old, using a human capital (log annual earnings) regression framework. Each earnings regression includes measures of schooling attainment and a standard set of control variables. ${ }^{34}$ For males, we stratify by broad sector-non-

\footnotetext{
${ }^{34}$ The control variables include: a quartic in potential experience, race and nativity dummies, and the number of years in the United States for the foreign born.
} 
TABLE 4

RETURNS TO EDUCATION BY TYPE OF SCHOOLING: MALES, 18- TO 65-YEARS OLD BY FARM AND NONFARM OCCUPATIONS

\begin{tabular}{|c|c|c|c|c|c|c|}
\hline & \multicolumn{2}{|c|}{ All Occupations } & \multicolumn{2}{|c|}{ Nonfarm Occupations } & \multicolumn{2}{|c|}{ Farm Occupations } \\
\hline & (1) & (2) & (3) & (4) & (5) & (6) \\
\hline Common school, years & $\begin{array}{c}0.0427 \\
(0.00269)\end{array}$ & & $\begin{array}{l}0.040 \\
(0.00300)\end{array}$ & & $\begin{array}{l}0.0375 \\
(0.00555)\end{array}$ & \\
\hline Grammar school, years & $\begin{array}{c}0.0533 \\
(0.00292)\end{array}$ & & $\begin{array}{c}0.0647 \\
(0.00304)\end{array}$ & & $\begin{array}{c}0.0232 \\
(0.00800)\end{array}$ & \\
\hline High school, years & $\begin{array}{l}0.103 \\
(0.00448)\end{array}$ & & $\begin{array}{l}0.102 \\
(0.00401)\end{array}$ & & $\begin{array}{l}0.114 \\
(0.0146)\end{array}$ & \\
\hline College, years & $\begin{array}{l}0.103 \\
(0.00604)\end{array}$ & & $\begin{array}{l}0.106 \\
(0.00520)\end{array}$ & & $\begin{array}{c}0.132 \\
(0.0254)\end{array}$ & \\
\hline \multicolumn{7}{|l|}{ Linear spline functions } \\
\hline $\begin{array}{l}\text { Common school, } \\
\text { years } \leq 9\end{array}$ & & $\begin{array}{c}0.0452 \\
(0.00336)\end{array}$ & & $\begin{array}{c}0.0454 \\
(0.00352)\end{array}$ & & $\begin{array}{c}0.0322 \\
(0.00756)\end{array}$ \\
\hline $\begin{array}{l}\text { Common school, } \\
\quad \text { years }>9\end{array}$ & & $\begin{array}{c}0.0291 \\
(0.00771)\end{array}$ & & $\begin{array}{l}0.00257 \\
(0.0111)\end{array}$ & & $\begin{array}{c}0.0462 \\
(0.0132)\end{array}$ \\
\hline $\begin{array}{l}\text { Grammar school, } \\
\quad \text { years } \leq 9\end{array}$ & & $\begin{array}{c}0.0547 \\
(0.00340)\end{array}$ & & $\begin{array}{c}0.0685 \\
(0.00341)\end{array}$ & & $\begin{array}{c}0.0159 \\
(0.00941)\end{array}$ \\
\hline $\begin{array}{l}\text { Grammar school, } \\
\quad \text { years }>9\end{array}$ & & $\begin{array}{c}0.0467 \\
(0.0195)\end{array}$ & & $\begin{array}{c}0.0233 \\
(0.0175)\end{array}$ & & $\begin{array}{c}0.122 \\
(0.0598)\end{array}$ \\
\hline High school, years $\leq 4$ & & $\begin{array}{l}0.111 \\
(0.00491)\end{array}$ & & $\begin{array}{l}0.111 \\
(0.00437)\end{array}$ & & $\begin{array}{c}0.122 \\
(0.0163)\end{array}$ \\
\hline High school, years $>4$ & & $\begin{array}{l}-0.0515 \\
(0.0329)\end{array}$ & & $\begin{array}{l}-0.0574 \\
(0.0318)\end{array}$ & & $\begin{array}{c}0.00817 \\
(0.0815)\end{array}$ \\
\hline $\begin{array}{c}\text { Years of college } \times \text { (if years } \\
\text { of high school }>0)\end{array}$ & & $\begin{array}{c}0.0958 \\
(0.00729)\end{array}$ & & $\begin{array}{c}0.0977 \\
(0.00607)\end{array}$ & & $\begin{array}{c}0.138 \\
(0.0408)\end{array}$ \\
\hline $\begin{array}{l}\text { Years of college } \times \text { (if years } \\
\text { of high school }=0 \text { ) }\end{array}$ & & $\begin{array}{c}0.0398 \\
(0.0172)\end{array}$ & & $\begin{array}{c}0.0532 \\
(0.0158)\end{array}$ & & $\begin{array}{c}0.0383 \\
(0.0547)\end{array}$ \\
\hline $\begin{array}{l}\text { College but no high } \\
\text { school, dummy }\end{array}$ & & $\begin{array}{l}0.265 \\
(0.0491)\end{array}$ & & $\begin{array}{l}0.290 \\
(0.0500)\end{array}$ & & $\begin{array}{c}0.231 \\
(0.120)\end{array}$ \\
\hline Business school, dummy & $\begin{array}{l}0.379 \\
(0.0850)\end{array}$ & $\begin{array}{c}0.371 \\
(0.0849)\end{array}$ & $\begin{array}{c}0.393 \\
(0.0705)\end{array}$ & $\begin{array}{c}0.381 \\
(0.0703\end{array}$ & & \\
\hline Native-born & $\begin{array}{l}0.222 \\
(0.0252)\end{array}$ & $\begin{array}{c}0.214 \\
(0.0252)\end{array}$ & $\begin{array}{l}0.178 \\
(0.0253)\end{array}$ & $\begin{array}{c}0.162 \\
(0.0253)\end{array}$ & $\begin{array}{c}0.262 \\
(0.0593)\end{array}$ & $\begin{array}{c}0.259 \\
(0.0593)\end{array}$ \\
\hline $\begin{array}{l}\left.\text { (Years in U.S. } \times 10^{-2}\right) \times \\
\text { foreign-born }\end{array}$ & $\begin{array}{c}0.677 \\
(0.0923)\end{array}$ & $\begin{array}{c}0.662 \\
(0.0922)\end{array}$ & $\begin{array}{c}0.409 \\
(0.0943)\end{array}$ & $\begin{array}{l}0.375 \\
(0.0941)\end{array}$ & $\begin{array}{c}0.913 \\
(0.218)\end{array}$ & $\begin{array}{c}0.905 \\
(0.218)\end{array}$ \\
\hline$R^{2}$ & 0.199 & 0.202 & 0.256 & 0.262 & 0.209 & 0.211 \\
\hline Standard error & 0.624 & 0.623 & 0.546 & 0.544 & 0.702 & 0.702 \\
\hline Number of observations & 14,699 & 14,699 & 10,695 & 10,695 & 3,705 & 3,705 \\
\hline
\end{tabular}

Notes: The dependent variable is log (annual earnings). The samples exclude the bottom 0.2 percent of the earnings distribution (less than $\$ 60$ ) and are restricted to those out of school. The regressions also contain a quartic in potential experience, a race dummy, and a dummy variable for those missing "years in the U.S." Potential experience is defined as $\min$ (age - 15, age - years of schooling - 7). All regressions are weighted by urban and rural sampling weights (see the Data Appendix for weighting information). Figures in parentheses are standard errors.

Source: Iowa 1915 sample (see the Data Appendix).

farm and farm. Education returns are estimated in two manners in Table 4. The first method (odd-numbered columns) includes separate variables for years of education by type of school. The second (even- numbered columns) uses a linear spline function by type and years of schooling. The reason for 
TABLE 5

RETURNS TO EDUCATION BY TYPE OF SCHOOLING: MALES AND UNMARRIED FEMALES, 18- TO 34-YEARS OLD

\begin{tabular}{|c|c|c|c|c|}
\hline & \multicolumn{3}{|c|}{ Males, 18- to 34-Years Old } & \multirow{2}{*}{$\begin{array}{c}\text { Unmarried Females } \\
\text { 18- to 34-Years Old } \\
\begin{array}{c}\text { (4) } \\
\text { All Occupations }\end{array}\end{array}$} \\
\hline & $\begin{array}{c}\text { (1) } \\
\text { All } \\
\text { Occupations }\end{array}$ & $\begin{array}{c}(2) \\
\text { Nonfarm } \\
\text { Occupations }\end{array}$ & $\begin{array}{c}\text { (3) } \\
\text { Farm } \\
\text { Occupations }\end{array}$ & \\
\hline Common school, years & $\begin{array}{c}0.0483 \\
(0.00395)\end{array}$ & $\begin{array}{c}0.0375 \\
(0.00442)\end{array}$ & $\begin{array}{c}0.0637 \\
(0.00837)\end{array}$ & $\begin{array}{c}0.00714 \\
(0.00877)\end{array}$ \\
\hline Grammar school, years & $\begin{array}{c}0.0693 \\
(0.00421)\end{array}$ & $\begin{array}{c}0.0671 \\
(0.00443)\end{array}$ & $\begin{array}{c}0.0568 \\
(0.0110)\end{array}$ & $\begin{array}{c}0.0454 \\
(0.00903)\end{array}$ \\
\hline High school, years & $\begin{array}{c}0.120 \\
(0.00564)\end{array}$ & $\begin{array}{c}0.114 \\
(0.00516)\end{array}$ & $\begin{array}{c}0.132 \\
(0.0176)\end{array}$ & $\begin{array}{c}0.101 \\
(0.00760)\end{array}$ \\
\hline College, years & $\begin{array}{c}0.146 \\
(0.00915)\end{array}$ & $\begin{array}{c}0.143 \\
(0.00799)\end{array}$ & $\begin{array}{c}0.166 \\
(0.0381)\end{array}$ & $\begin{array}{c}0.151 \\
(0.0122)\end{array}$ \\
\hline Business school, dummy & $\begin{array}{c}0.284 \\
(0.0988)\end{array}$ & $\begin{array}{c}0.273 \\
(0.0831)\end{array}$ & & $\begin{array}{c}0.508 \\
(0.0969)\end{array}$ \\
\hline Native born & $\begin{array}{c}0.210 \\
(0.0324)\end{array}$ & $\begin{array}{c}0.145 \\
(0.0330)\end{array}$ & $\begin{array}{c}0.284 \\
(0.0766)\end{array}$ & $\begin{array}{c}0.0422 \\
(0.0765)\end{array}$ \\
\hline $\begin{array}{l}\left.\text { (Years in U.S. } \times 10^{-2}\right) \times \\
\text { foreign born }\end{array}$ & $\begin{array}{c}1.14 \\
(0.223)\end{array}$ & $\begin{array}{c}0.497 \\
(0.238)\end{array}$ & $\begin{array}{c}1.78 \\
(0.489)\end{array}$ & $\begin{array}{l}0.0188 \\
(0.554)\end{array}$ \\
\hline$R^{2}$ & 0.251 & 0.296 & 0.241 & 0.273 \\
\hline Standard error & 0.567 & 0.501 & 0.645 & 0.546 \\
\hline Number of observations & 7,145 & 5,249 & 1,784 & 2,001 \\
\hline
\end{tabular}

" "Unmarried" means single, widowed, divorced, or separated.

Notes: The dependent variable is log (annual earnings). The samples exclude the bottom 0.2 percent of the earnings distribution and are restricted to those out of school. The regressions also contain a quartic in potential experience, a race dummy, and a dummy variable for those missing "years in the U.S." All regressions are weighted by urban and rural sampling weights (see the Data Appendix for weighting information). Figures in parentheses are standard errors.

Source: Iowa 1915 sample (see the Data Appendix).

estimating the linear spline function is, as we have already noted, that many Americans in 1915 had attended common (and grammar) school for more than the usual eight (or nine) years and a large fraction of those who attended college never went to high school. ${ }^{35}$ We are able to evaluate whether earnings were augmented by the additional years in common (or grammar) school beyond the usual eight or nine, as well as what was meant by years of college for those who never attended high school. The estimates we report are robust to the inclusion of other (exogenous) covariates (for example, nationality, parental nativity) and are not much altered by including controls

\footnotetext{
${ }^{35}$ Among males 18- to 65-years old (with positive earnings) who attended at least one year of college, 30 percent claimed to have had no years of high school, and among a similar group of females 19 percent listed no years of high school. For male farmers who attended at least a year of college, 59 percent had attended no high school. College attendees from rural areas would have been less able to attend the town high school and would, most probably, have gone to the preparatory department of the state university. "College" may have included commercial institutes, although they were often listed separately as "business schools" and coded as such in our data.
} 
for church affiliation and location. ${ }^{36}$ We also include, in each specification, an indicator variable for whether an individual attended a business or commercial school. ${ }^{37}$

The Iowa State Census of 1915 asked the amount earned from the individual's occupation. Even though Iowa had no income tax in 1915, individuals may have been reluctant to provide income information or may have been unable to assess it accurately. In the "city sample" just 3.8 percent refused to answer the income question (or did not answer it for other reasons) and in the "rural sample" 7.1 percent refused (4.4 percent among farmers) ${ }^{38}$ In contrast, in recent March Current Population Surveys 15 to 20 percent of wage and salary earners and 25 to 30 percent of the self-employed were unwilling to report their income. ${ }^{39}$ Farmers, like other self-employed individuals, had to decide whether income should be net of costs or gross. A comparison of the value of per farm gross product in lowa in 1910 with mean farm earnings reported in the Iowa State Census of 1915 strongly suggests that farmers reported income net of various expenditures. ${ }^{40}$

Across all occupations (Table 4, col. 1) the return to a year in common or grammar school was 4 to 5 percent, whereas that for high school or college was double the rate-around 10 percent. Returns were somewhat higher for the younger group (Table 5, col. 1), for which a year in high school garnered 12 percent and a year of college, 15 percent. Similarly for young, unmarried

\footnotetext{
${ }^{36}$ See Appendix Tables A1 and A2 for estimates on different sub-samples and with more control variables. The coefficients on the control variables appear qualitatively similar to those from earningsfunction estimates using recent, national data. In particular, we find a steep, upward sloping, and concave experience-earnings profile for males, with earnings increasing by about 8 percent per year in the first decade of labor market experience and peaking at around 33 years of experience. A dummy variable for being married slightly reduces the educational coefficients for males but is the only additional control that makes a difference. The inclusion of the married dummy is questionable because it could be endogenous to labor-market success. The other variables-years in lowa, having foreign-born parents, urban and church-affiliation dummies - have little impact on the schooling coefficients. There are also a substantial urban wage premium and a wage penalty to immigrants that narrows with years in the United States. Unemployment was more common for the less educated and the inclusion of months unemployed modestly reduces the education premium. Returns to high school and college are far higher for the native-born than for foreign-born Europeans.

${ }^{37}$ The estimates of schooling returns are not sensitive to including the "business school" dummy.

${ }^{38}$ In most cases, a refusal to provide income information was indicated by the assessors, but in other cases we inferred refusal from the reporting of an occupation (for those not retired), less than 12 months unemployment, and no income listed. In the rural, nonfarmer sample almost 10 percent did not report an income. Interestingly, most individuals in rural areas would have known their assessor for they were almost always from the same township.

${ }^{39}$ Lillard, Smith, and Welch, "What Do We Really Know about Wages?"

${ }^{40}$ The value of products, including all crops, and dairy, poultry, and miscellaneous farm products (but excluding items consumed by the farm household) was $\$ 1,744$ per farm (U.S. Bureau of the Census, Thirteenth Census, 1910, Vol. 6). The value of animals sold or slaughtered on the farm $(\$ 1,005 /$ farm) is not included since it is impossible to net out the value of farm crops fed to animals. Because net farm income would include the value added of the animals sold, gross farm income would have exceeded $\$ 1,744$ per farm. Since the values are for 1910 and farm incomes rose in the early 1910 s, these are lower bound values to gross farm income in 1914. Mean occupational earnings reported by farmers for 1914 in our Iowa sample is $\$ 1,048$, considerably less than gross earnings.
} 
women (Table 5, column 4), a year of high school returned 10 percent and a year of college 15 percent. Grammar school rates of return were lower for females than for males and common school rates of return were practically zero for young women. We will show that about half of the return to a year of post-grammar schooling came from switching between blue- and whitecollar jobs for males in the nonfarm group. For females, however, almost all the return came from the occupational shift to clerical work and teaching.

The higher return to a year of college for the younger group deserves further comment. The issue is whether a college education changed over time and whether the colleges generally attended by the older group were different from those of the younger. Many of Iowa's older college-educated population had attended small denominational liberal arts colleges and bible schools characteristic of the nineteenth century. The return to a year in these older-style colleges may not have been as high as a year in a state university or in the larger, more modern liberal arts colleges attended by the younger group. ${ }^{41}$

Of great importance in a state having 39 percent of its male labor force in farming, is the premium to post-common-school years in the farm-sector sample (Table 4, column 5). Although the return to the elementary grades was a bit lower for those in the farm sector, there was a hefty return for years at the high school and college levels. ${ }^{42}$ (We later evaluate the relationship between education and farm productivity using cross-county data for which we can include the value of land and capital.)

The linear spline function estimates (Table 4, even columns) reveal that almost nothing was gained from years beyond nine in common or grammar school, or from those above four in high school, by those in nonfarm occupations. Rather than substituting for secondary school, most of the added years appear to have been taken by "retained" students. For those in farm occupations, however, years beyond nine in common school had some value, possibly because many of these adults could not, as rural children, attend the geographically distant-and expensive-secondary schools in town. ${ }^{43}$ In addition, the first four years of high school have an even greater return than in the even-numbered columns-more than 11 percent per annum in both the farm and nonfarm sectors-and years beyond four have no return.

\section{Educational Returns in Blue-Collar Versus White-Collar Occupations.}

Not only were returns to education considerable within the farm sector (as in Table 5, column 3), they were also substantial among those in the blue-

\footnotetext{
${ }^{41}$ For a discussion of the change in college curriculum see Goldin and Katz, "Shaping."

${ }^{42}$ Among male farmers 18- to 65-years old with positive earnings, about 13 percent had at least either a year of high school or college.

${ }^{43}$ Note that the curious coefficient on "grammar school years greater than nine" (Table 4, column 6) should be discounted since the number of observations in that cell is small.
} 
TABLE 6

RETURNS TO EDUCATION BY TYPE OF SCHOOLING: MALES AND UNMARRIED FEMALES BY AGE AND OCCUPATIONAL GROUPS (NONFARMER)

\begin{tabular}{|c|c|c|c|c|c|}
\hline & \multicolumn{2}{|c|}{ 18- to 65 -Years Old } & \multicolumn{3}{|c|}{ 18- to 34-Years Old } \\
\hline & \multicolumn{2}{|c|}{ Males } & \multicolumn{2}{|c|}{ Males } & \multirow{2}{*}{$\begin{array}{c}\text { Unmarried } \\
\text { Females }^{\mathbf{a}}\end{array}$} \\
\hline & $\begin{array}{c}\text { (1) } \\
\text { Blue-Collar } \\
\text { Occupations }\end{array}$ & $\begin{array}{c}\text { (2) } \\
\text { White-Collar } \\
\text { Occupations }\end{array}$ & $\begin{array}{c}\text { (3) } \\
\text { Blue-Collar } \\
\text { Occupations }\end{array}$ & $\begin{array}{l}\text { (4) } \\
\text { White-Collar } \\
\text { Occupations }\end{array}$ & \\
\hline Common school, years & $\begin{array}{c}0.0239 \\
(0.00314)\end{array}$ & $\begin{array}{c}0.0275 \\
(0.00573)\end{array}$ & $\begin{array}{c}0.0229 \\
(0.00450)\end{array}$ & $\begin{array}{c}0.0438 \\
(0.00889)\end{array}$ & $\begin{array}{c}0.00901 \\
(0.00975)\end{array}$ \\
\hline Grammar school, years & $\begin{array}{c}0.0585 \\
(0.00320)\end{array}$ & $\begin{array}{c}0.0470 \\
(0.00591)\end{array}$ & $\begin{array}{c}0.0634 \\
(0.00458)\end{array}$ & $\begin{array}{c}0.0679 \\
(0.00909)\end{array}$ & $\begin{array}{c}0.0396 \\
(0.0100)\end{array}$ \\
\hline High school, years & $\begin{array}{c}0.0740 \\
(0.00584)\end{array}$ & $\begin{array}{c}0.0609 \\
(0.00566)\end{array}$ & $\begin{array}{c}0.0908 \\
(0.00738)\end{array}$ & $\begin{array}{c}0.0826 \\
(0.00747)\end{array}$ & $\begin{array}{c}0.0666 \\
(0.00846)\end{array}$ \\
\hline College, years & $\begin{array}{c}0.0533 \\
(0.0151)\end{array}$ & $\begin{array}{c}0.0783 \\
(0.00569)\end{array}$ & $\begin{array}{c}0.0575 \\
(0.0195)\end{array}$ & $\begin{array}{l}0.131 \\
(0.00849)\end{array}$ & $\begin{array}{c}0.119 \\
(0.0115)\end{array}$ \\
\hline Business school, dummy & $\begin{array}{c}0.441 \\
(0.156)\end{array}$ & $\begin{array}{l}0.202 \\
(0.0776)\end{array}$ & $\begin{array}{c}0.452 \\
(0.180)\end{array}$ & $\begin{array}{c}0.0825 \\
(0.0886)\end{array}$ & $\begin{array}{c}0.384 \\
(0.0899)\end{array}$ \\
\hline Native born & $\begin{array}{c}0.132 \\
(0.0240)\end{array}$ & $\begin{array}{c}0.144 \\
(0.0653)\end{array}$ & $\begin{array}{c}0.125 \\
(0.0316)\end{array}$ & $\begin{array}{l}0.120 \\
(0.0940)\end{array}$ & $\begin{array}{l}-0.810 \\
(0.233)\end{array}$ \\
\hline $\begin{array}{l}\left.\text { (Years in U.S. } \times 10^{-2}\right) \times \\
\text { foreign-born }\end{array}$ & $\begin{array}{c}0.454 \\
(0.0981)\end{array}$ & $\begin{array}{c}0.309 \\
(0.211)\end{array}$ & $\begin{array}{c}0.570 \\
(0.249)\end{array}$ & $\begin{array}{c}0.762 \\
(0.569)\end{array}$ & $\begin{array}{l}-2.23 \\
(1.23)\end{array}$ \\
\hline$R^{2}$ & 0.205 & 0.218 & 0.256 & 0.313 & 0.226 \\
\hline Standard error & 0.506 & 0.539 & 0.484 & 0.478 & 0.491 \\
\hline Number of observations & $\mathbf{7 , 5 8 8}$ & 3,733 & 4,021 & 1,744 & 1,248 \\
\hline
\end{tabular}

"Unmarried" means single, widowed, divorced, or separated.

Notes: The dependent variable is log (annual earnings). The samples exclude the bottom 0.2 percent of the earnings distribution (males earning less than $\$ 60$; females earning less than $\$ 30$ ) and are restricted to those out of school. The regressions also contain a quartic in potential experience, a race dummy, and a dummy variable for those missing "years in the U.S." All regressions are weighted by urban and rural sampling weights (see the Data Appendix for weighting information). Blue-collar occupations include those in craft, operative, service, and laborer occupations (codes 300 to 988 using the 1940 occupational classification). White-collar occupations include those in professional, semiprofessional, managerial (excluding farming), clerical, and sales occupations (codes 1 to 45, and 100 to 299 using the 1940 occupational classification). Figures in parentheses are standard errors.

Source: Iowa 1915 sample (see the Data Appendix).

collar labor force (as in Table 6, column 1 and column 3). Thus even though higher returns were garnered by individuals who moved between sectors, such as from blue- to white-collar jobs, there were reasonably high returns to each year of high school within the blue-collar (operative, craft, service, and laborer) group. ${ }^{44}$ For 18 - to 34 -year old males, for example, the return

\footnotetext{
${ }^{44}$ The role of within- and between-occupation returns to education can be demonstrated more clearly by adding a full set of occupation dummies to the regressions in Tables 4,5 , and 6 . For males 18 - to 65 -years old the addition of one-digit occupation dummies to the basic regression in column 1 of Table 4 reduces the return to a year of high school from 0.103 to 0.062 . The inclusion of a full set of threedigit dummies lowers it to 0.054 . Thus, for males, about half of the return to high school results from moving into better paying occupations and half remains even within detailed occupations. Comparable analysis for the blue-collar group separately results in similar findings. The return to years of high school was about equally divided between that due to higher earnings within narrowly defined occupa-
} 
to a year of high school drops minimally from 11.4 percent for all nonfarm occupations (Table 5, column 2) to 9.1 percent for all blue-collar occupations (Table 6 , column 3 ).

One may wonder what high school educated blue-collar workers were doing in Iowa in 1915. Many high-technology industries of the day (for example, business and electrical machinery, nonferrous metals) and those using either continuous-process methods (for example, oats, film) or batch technologies (for example, dairy, chemicals, petroleum refining) demanded high school educated blue-collar workers in $1915 .{ }^{45}$ But Iowa did not have much industry and that which it did have was not disproportionately in the high-technology and high-education group. Many of Iowa's blue-collar workers were not working in manufacturing firms at all, but were, rather, employed in small repair shops or by the railroad. Because industry was not asked in the 1915 Iowa State Census, we cannot always discern it. We do know that high school educated blue-collar workers in Iowa were far less often "laborers" than their less-educated counterparts, and were disproportionately in skilled occupations (for example, electrician, machinist) ${ }^{46}$ Our best guess, therefore, is that the ability to read and comprehend manuals, decipher blue-prints, do algebra, and solve formulas - a few of the skills provided in even small-town high schools - were valued by a wide range of employers. ${ }^{47}$

Similar findings hold even more forcefully for the white-collar group. Returns to a year of high school are lower in the within- as opposed to the between-occupational group analysis (that is, Table 6 , column 4 versus Table 5, column 2), but the reduction is modest. Furthermore, the addition of a full set of white-collar occupation dummies to the Table 6, column 4 estimates minimally reduces the high school coefficient and does little to that on college. Educational returns in the white-collar sector were primarily due to within occupation differences.

tions and that due to a shift to higher-paying occupations. A greater proportion of electricians and machinists, for example, were high school graduates and these occupations paid considerably more than did others in the blue-collar group. But within most blue-collar occupations, more education also increased earnings.

${ }^{45}$ Goldin and Katz, "Origins."

${ }^{46}$ Among nonfarm blue-collar workers without a high school education 44 percent were laborers or teamsters, compared with 20 percent among those with some high school (for males 18- to 34-years old). Similarly, 48 percent were craft workers among those with some high school, whereas 29 percent were for those without high school.

${ }^{47}$ Most lowa high schools in the period before 1915 would not have had shop facilities, but they did have laboratories and often gave courses in bookkeeping (of the approximately 600 high schools in 1903 about 70 percent offered bookkeeping). But in general, the high school curriculum in most lowa schools would have been more classically oriented than in the nation's large cities and than in Iowa in the years to come. 


\section{Returns to Education among Farmers}

The finding of substantial returns to high school and college education for the farm population is a result of some importance, for the widespread support of education in the state of Iowa came from a mainly agricultural population. The demand for high schools was voiced not just by those in the towns and cities of Iowa, but also by many on the farm. In the farm press and the state school reports, the loss to a farm community in not having a high school in easy access of the farm children was a constant source of frustration. Farmers often retired when their eldest was ready for high school or, alternatively, parents remained on the farm and sent their children to board in the town. "The country school," noted the progressive Des Moines farm journal Wallace's Farmer, "will remove one of the inducements that leads farmers to retire in the town. The most potent of these inducements is that of giving children a better education." "48 It also warned that: "Farmers of the districts have been watching their boys and girls going to town schools and acquiring ideas that take them ultimately away from the farm.."49

Ironically perhaps, high school education in this mainly agricultural state often meant greater geographic mobility with or without a school close to the farm. But many in the farm community supported the funding of high schools, and in retrospect such support was highly rational. If there were no high school in the community, those desiring education would leave farming earlier or send their children to the town. Although a greater fraction of educated farm youth would eventually leave farming, others would become more productive farmers. We explore this possibility using county-level data.

The published versions of the 1915 and 1925 Iowa State Censuses provide education information for the adult population in the 99 counties of Iowa. ${ }^{50}$ The agricultural censuses of 1910 and 1920 contain the value of crops produced per farm and various inputs, such as the number of acres and the value of machinery and implements per farm, also by county. ${ }^{51}$ We have, therefore, two cross sections to explore whether high school education was related to agricultural productivity by county, given county inputs and a measure of soil quality. We can also difference the two years to see if increased productivity was related to increased high school education, given input changes.

${ }^{48}$ Wallace's Farmer, 18 April 1913, p. 691.

${ }^{49}$ Ibid., 21 March 1913, p. 519.

${ }^{50}$ The 1925 Iowa State Census is similar in certain respects to that for 1915, but did not ask income. It did inquire of education at various levels.

${ }^{51}$ The output measure we use for 1910 and 1920 is the total value of crops produced per farm. That given for 1930 is the value of output sold per farm. The difference lies in the fact that a large part of the marketed output was in the form of animals and their products for which the crops are an input. The 1930 data may provide the better output measure, but we cannot use it to produce the difference estimate in cotumn 3 of Table 7 . We have verified that using the 1930 output and input data produce results virtually identical to those in column 2 . The number of farmers is nearly identical to the number of farms. 
The implicit framework, given by equation 1 , is a simple Cobb-Douglas production function in which output per farm (or per farmer), $(Q / L)$, is a function of machinery per farm, $(K / L)$, and land per farm, $(T / L)$, each raised to the appropriate output elasticity $(\beta, \gamma)$. Education $(E)$, as given by the fraction of adults (older than 20 years) with at least some high school or college education, and the various soil types $\left(S_{i}\right)$ shift the production function.

$$
(Q / L)=A \cdot(K / L)^{\beta} \cdot(T / L)^{\gamma} \cdot \exp ^{\delta E+\sum \lambda_{i} S_{i}}
$$

We estimate equation 1 in logs across the 99 counties of Iowa for 1915 and 1925, and the results are given in Table 7, columns 1 and 2 . In both cases, the coefficients on the education variable are positive, statistically significant, and of consequential magnitude. Increasing the fraction of adults in the county who attended any high school or college by one standard deviation ( 0.0434 ) increases crop value per farm by 5.6 percent in 1915; similarly for 1925 , increasing education by one standard deviation $(0.0560)$ increases farm crop value by 5.2 percent. ${ }^{52}$ The relationship, moreover, holds when we estimate the equation in difference form, as in column $3 .{ }^{53}$ Thus both the individual-level data for farmers (Table 5) and the county-level data (Table 7) indicate a strong positive connection between earnings or farm productivity, and education.

Much has been written about the role of education in enhancing agricultural productivity. ${ }^{54}$ Although the mechanisms are several, one stands out. In periods of technological change, the more educated are the first to be the adopters. High school and college educated Iowa farmers in the late 1920s and early 1930s adopted hybrid corn earlier than did other farmers. ${ }^{55} \mathrm{Al}-$ though the diffusion of hybrid corn and the tractor came after 1915, many other important technological advances, such as fertilizers, electric and steam powered equipment, animal inoculation, and accounting techniques, swept the countryside before. Even though few high school educated Iowans in 1915 had been taught agricultural science, most had received instruction in algebra, geometry, biology, chemistry, and bookkeeping.

In sum, the returns to high school and college education in 1915 were substantial-about 11 percent per year for all males and more than 12 per-

\footnotetext{
${ }^{52}$ The schooling effects double in magnitude when the machinery variable is excluded from the regression.

${ }^{53}$ The change in the value of crops is from 1910 to 1920 , but that for education is from 1915 to 1925. Although we would rather use the change in education preceding the change in crop values, we have no other data given the change in the farm production information in the 1930 census.

${ }^{34}$ See, for example, Huffman, "Human Capital"; Schultz, Transforming Traditional Agriculture; and Welch, "Education," who emphasizes that periods of technological change afforded an advantage to educated persons, particularly in agxiculture.

${ }^{35}$ Ryan and Gross, "Acceptance."
} 
TABLE 7

FARM PRODUCTIVITY AND EDUCATION: IOWA COUNTIES, 1915 AND 1925

\begin{tabular}{|c|c|c|c|c|c|c|}
\hline & \multicolumn{3}{|c|}{$\begin{array}{l}\text { Dependent Variable: log (crop value } \\
\left.\text { per farm } \times 10^{-3}\right), 1910 \text { or } 1920 \text { or } \\
\text { Difference }\end{array}$} & \multicolumn{3}{|c|}{ Means } \\
\hline & $\begin{array}{l}(1) \\
1915\end{array}$ & $\begin{array}{l}(2) \\
1925\end{array}$ & $\begin{array}{c}(3) \\
1925-1915 \\
\text { Difference }\end{array}$ & 1915 & 1925 & $\begin{array}{c}(6) \\
1925-1915 \\
\text { Difference }\end{array}$ \\
\hline Dependent variable & & & & 0.345 & 1.40 & 1.05 \\
\hline $\begin{array}{l}\log (\text { machinery value per } \\
\left.\text { farm } \times 10^{-3}\right), 1910 \text { or } \\
1920 \text { or difference }\end{array}$ & $\begin{array}{c}0.814 \\
(0.0835)\end{array}$ & $\begin{array}{c}0.820 \\
(0.0533)\end{array}$ & $\begin{array}{c}0.577 \\
(0.102)\end{array}$ & -0.834 & 0.343 & 1.177 \\
\hline $\begin{array}{l}\text { Log }(\text { land in acres per } \\
\left.\text { farm } \times 10^{-3}\right), 1910 \text { or } \\
1920 \text { or difference }\end{array}$ & $\begin{array}{c}0.130 \\
(0.0928)\end{array}$ & $\begin{array}{c}0.215 \\
(0.0835)\end{array}$ & $\begin{array}{c}0.104 \\
(0.200)\end{array}$ & -1.85 & -1.84 & 0.00414 \\
\hline $\begin{array}{l}\text { Fraction with any high } \\
\text { school or college }>20 \\
\text { years old, } 1915 \text { or } \\
1925 \text { or difference }\end{array}$ & $\begin{array}{l}1.30 \\
(0.270)\end{array}$ & $\begin{array}{c}0.927 \\
(0.165)\end{array}$ & $\begin{array}{l}1.17 \\
(0.432)\end{array}$ & 0.228 & 0.328 & 0.102 \\
\hline$R^{2}$ & 0.845 & 0.917 & 0.324 & & & \\
\hline Standard error & 0.100 & 0.0821 & 0.116 & & & \\
\hline Number of observations & 99 & 99 & 99 & & & \\
\hline
\end{tabular}

Notes: Years in the column headings refer to the year of the educational information. Crop value, machinery value, and land in acres per farm are for 1910 in columns 1 and 4, and for 1920 in columns 2 and 3. Fraction with any high school or college is for 1915 in columns 1 and 4, and 1925 in columns 2 and 4. Regressions in columns 1 and 2 also include four soil-type dummies (Missouri loess, lowa drift, Mississippi loess, and South Iowa loess), a dummy variable for Polk county (Des Moines), and a dummy variable indicating whether the county is on either the Mississippi or the Missouri rivers. The land types are from State of Iowa, Thirteenth Annual Iowa Yearbook, p. 670. Figures in parentheses are standard errors.

Sources: The education variable is from State of Iowa, Census of Iowa, 1915 and Census of Iowa, 1925; all other variables in the table are from U.S. Bureau of the Census, Thirteenth Census, Vol. 6, and Fourteenth Census, 1920.

cent for younger male workers. Enhanced earnings with increased education at the secondary-school level existed within broad classes of occupations. Blue-collar workers with a high school education earned substantially more than did other blue-collar workers, and the same was true, even more so, for white-collar workers. Farmers with secondary-school or college training earned considerably more than other farmers, and counties with a greater percentage of high school-and college-educated adults had higher agricultural productivity. Because Iowa led in education in the early twentieth century our estimates could be downwardly biased compared with most other states.

\section{RETURNS TO EDUCATION IN THE FIRST HALF OF THE TWENTIETH CENTURY}

It is now widely acknowledged that the return to years of secondary and college education was substantial in 1940 but that the decade of 1940 s saw 
a marked reduction in the educational wage premium and a narrowing of the wage structure generally ${ }^{56}$ The "Great Compression" of the 1940 s, as it has been dubbed, witnessed changes in the wage structure there were as wideranging and as great in magnitude as those more recently experienced. But the changes were reverse in direction and occurred in a far shorter period. One reason offered for the narrowing of the wage structure and the decrease in the educational premium in the 1940s is the large increase in the relative supply of educated workers in 1930s and 1940s. But secondary-school expansion began much earlier and each successive year brought a new and even larger cohort of high school-educated youth into the labor force. Even though the return to years of high school was substantial in 1940, it may have been even higher in 1915.

An estimate of the increase in educational attainment before 1950 has been hindered by data deficiencies. Given the overstatement of school years for older cohorts in the 1940 census, the increase in the educational stock derived from those data would be understated. ${ }^{57}$ But, as we have shown elsewhere, the overstatement in the 1940 census is minimal for Iowa-born men and the bias is small for the younger groups. ${ }^{58}$

By using the Iowa data for 1915 and 1940, we can obtain a reliable estimate of the increase in the fraction of the male labor force with secondary schooling. In 1915, 17.4 percent of 25 - to 40 -year old men (14.8 percent of 25- to 65-year old men) in lowa had graduated from high school (or went to college); in 1940, 36.5 percent (26.0 percent) -double the 1915 level-had, and by 195052.8 percent (39.1 percent) had. Given the expansion in high school across those years, the returns to secondary schooling may have declined, first from 1915 to 1940 and again in the 1940s..$^{59}$ The information in the Iowa State Census for 1915, together with that for Iowa residents in the 1940, 1950, and 1960 IPUMS, will allow us to evaluate whether the returns to post-elementary education were higher before 1940 than after.

Several data problems must first be addressed regarding comparability across the censuses. The 1940 federal census asked wage and salary income, not self-employment income, whereas the 1915 Iowa State Census asked income from occupation without distinguishing between self-employment and wage and salary income. Fortunately, the 1950 and 1960 censuses contain separate data for the two income categories. By focusing only on the nonfarm population in all years, we can eliminate a major group of the self-

\footnotetext{
${ }^{56}$ See Goldin and Margo, "Great Compression."

${ }^{57}$ Increases in the quality of education, mainly from an increase in the school term, reinforce the understatement in the growth of the educational stock. Note, however, that the school term in Iowa, even in 1900, was already nine months in most districts.

${ }^{58}$ On the first point, see the working-paper version of this article, Goldin and Katz, "Education," and on the second point, see Goldin, "America's Graduation."

${ }^{39}$ The data on educational attainment use the version 1 definition in Table 1.
} 
employed. But we are still left with potential problems of comparability between 1940 and the other years because relatively more college-educated men were self-employed among the nonfarm group. The results for 1950 and 1960 are, therefore, presented with and without the self-employed, and they will form the basis of our adjustments to the 1940 data to render them comparable with 1915. The 1960 census is included because education and earnings in 1950 are given for sample-line individuals only. The larger 1960 sample enables more precise estimates of the returns to education in Iowa.

Another data issue of importance concerns unemployment. The national unemployment rate was unusually high in 1939, toward the end of the Great Depression, but was moderate in 1914, 1949, and 1959 (the years of the census income question). We report the estimates of the educational returns for full-year workers in all censuses, but show (in Appendix Table A3) that the inclusion of part-year workers greatly increases the return to education in 1939.

Finally, there is the issue concerning whether results using the Iowa data are representative of national trends. We find that educational wage differentials move similarly in Iowa and the United States from 1940 to $1960 .{ }^{60}$ Even though Iowans did not have occupations that were fully representative of the national population and Iowans were more educated in the period under question, the trend in the variable of interest is substantially the same for Iowa and the nation as a whole.

We summarize the educational return results in Table 8 for full-year, nonfarm male workers in Iowa. Comparing the 1940, 1950, and 1960 results for wage and salary earners only, there is a decrease in the return to years of high school and to years of all schooling for the full age group (18- to 65years old) and the younger group (18- to 34-years old). The decrease from 1940 to 1960 in returns to schooling are somewhat muted when the selfemployed are included in the 1950 data. $^{61}$

The most interesting comparison for the subject at hand is that between 1915 and the three later years. Returns to years of high school, college, and all schooling decreased from 1915 to 1950 , and also from 1915 to 1960 , using the comparable measures of income from both wage and salary and self-employment (Table 8, lines 1, 2, and 3). The decrease for years of high school is about 4 percentage points and that for years of all schooling is

\footnotetext{
${ }^{60}$ Goldin and Katz, "Returns." U.S. data show a steeper decline of education returns from 1940 to 1950 than in Iowa. The national data also show a modest recovery in returns from 1950 to 1960 , whereas the Iowa data reveal a continued but small decline. Changes in the overall 1940 to 1960 period are similar between the nation and Iowa for both high school and college returns. The small sample size for Iowa in 1950 leads us to rely on the 1940 to 1960 trend.

${ }^{61}$ One anomaly, relative to national data, is that the return to a year of college increases from 1940 to 1950 for the younger age group in lowa, when self-employment income is excluded. The anomaly disappears when the sample is expanded to include neighboring states.
} 
TABLE 8

RETURNS TO EDUCATION FOR FULL YEAR, NONFARM, MALE WORKERS IN IOWA: $1914,1939,1949$, AND 1959

\begin{tabular}{|c|c|c|c|c|c|c|}
\hline \multirow[b]{2}{*}{ Census Year } & \multicolumn{2}{|c|}{ Years of High School } & \multicolumn{2}{|c|}{ Years of College } & \multicolumn{2}{|c|}{$\begin{array}{c}\text { Linear in All Years of } \\
\text { Schooling }\end{array}$} \\
\hline & $\begin{array}{c}18-65 \\
\text { Years Old }\end{array}$ & $\begin{array}{c}18-34 \\
\text { Years Old }\end{array}$ & $\begin{array}{c}18-65 \\
\text { Years Old }\end{array}$ & $\begin{array}{c}18-34 \\
\text { Years Old }\end{array}$ & $\begin{array}{c}18-65 \\
\text { Years Old }\end{array}$ & $\begin{array}{c}18-34 \\
\text { Years Old }\end{array}$ \\
\hline (1) 1915 & 0.091 & 0.105 & 0.091 & 0.128 & 0.084 & 0.100 \\
\hline (2) 1950 & 0.051 & 0.067 & 0.073 & 0.086 & 0.054 & 0.069 \\
\hline (3) 1960 & 0.047 & 0.050 & 0.085 & 0.071 & 0.059 & 0.058 \\
\hline $\begin{array}{l}\text { (4) } 1940 \text {, wage and } \\
\text { salary earnings only }\end{array}$ & 0.064 & 0.097 & 0.081 & 0.086 & 0.064 & 0.075 \\
\hline $\begin{array}{l}\text { (5) } 1950 \text {, wage and } \\
\text { salary earnings only }\end{array}$ & 0.049 & 0.043 & 0.064 & 0.101 & 0.048 & 0.060 \\
\hline $\begin{array}{l}\text { (6) } 1960 \text {, wage and } \\
\text { salary earnings only }\end{array}$ & 0.040 & 0.049 & 0.064 & 0.057 & 0.046 & 0.050 \\
\hline (7) 1940, adjusted 1 & 0.064 & 0.097 & 0.094 & 0.095 & 0.068 & 0.079 \\
\hline (8) 1940 , adjusted 2 & 0.071 & 0.098 & 0.102 & 0.100 & 0.077 & 0.083 \\
\hline
\end{tabular}

Notes: See Appendix Table A3 for standard errors, for the other schooling coefficients, and for the results in the unrestricted sample of all male nonfarm workers. The coefficients listed for "years of high school" and "years of college" are those from a spline in years of education ( 1 to 8 years, 9 to 12 years, and 13 plus years) in a regression of (log) annual earnings. The coefficients listed for "linear in years of all schooling" are those from the sum of all years in school in a regression of (log) annual earnings. "Full year" is defined for 1940,1950 , and 1960 as more than 49 weeks of work; in 1915 it is defined as listing no unemployment. Controls in all regressions are: quartic in potential experience, whether native-born, and whether white. Each of the samples deletes the lowest 1 percent of earners. The samples for 1940, 1950, and 1960 include only those living in the state of Iowa.

The estimates in rows 7 and 8 adjust for differences in education returns for all workers and for wage and salary workers. Row 7 uses a national adjustment factor, whereas row 8 uses an Iowa adjustment. The 1940 adjusted 1 estimates, row 7 , take the 1940 wage and salary earnings estimates, row 4 , and add an adjustment factor to account for the absence of self employment income for comparability with the estimates in row 1 for 1915. This adjustment factor, for each column, is constructed from U.S. national estimates (not reported) because the sample used here (for Iowa) is small, particularly for 1950 . We take the difference in returns to each type of schooling for the entire U.S. sample and for the U.S. wage and salary sample, averaging the estimates for 1950 and 1960 , and then add this adjustment factor to the 1940 estimates in row 4 . The 1940 adjusted 2 estimates, row 8, use the differences in estimated returns in Iowa for the entire sample in row 3 and the wage and salary sample in row 6 as the adjustment factors in each column.

Sources: Iowa 1915 Sample; and 1940, 1950, and 1960 IPUMS.

about 3 percentage points from 1915 to 1960 . These declines are substantial and are about 35 percent of the 1915 level.

The comparison between returns to education in 1915 and 1940 is the most critical since it is already well known that returns declined from 1940 to 1950 . But the comparison is somewhat problematic. Self-employment income is included in the 1915 earnings measure but not in 1940. Ignoring these differences, for the moment, we find substantial declines, from 1915 to 1940 , in the returns to high school, college, and all years of schooling (for full-year, nonfarm male workers). The decline in the "all years of schooling" category is 2 to 2.5 percentage points; the others range from 0.8 for 
years of high school to 4.2 for years of college, both for the younger group (Table 8, rows 1 and 4).

But we cannot ignore the issue of self-employment income and have arrived at two methods of adjusting the 1940 results. Analysis of the 1950 and 1960 data reveals that returns to education are modestly greater when self-employment income is included in the earnings measure. We therefore adjust the estimates of returns to schooling in 1940 to account for the exclusion of self-employment income and present them in rows 7 and 8 in Table 8. The 1940 "adjusted 1" estimates use an adjustment factor based on national estimates for 1950 and 1960 of differences in returns to education between all workers and wage and salary employees. The 1940 "adjusted 2" estimates use an adjustment factor based on the 1960 data for Iowa.

The adjusted returns for 1940 are considerably lower than are those for 1915 in five of the six columns of Table 8. The one exception is the case of college years for all males, but, as noted before, this result may derive from the nature of colleges prior to 1900 . We are led to conclude that substantial declines in the returns to post-elementary education in Iowa occurred from 1915 to 1940 . Figure 2 illustrates the changes in returns to college and high school across the entire period, 1915 to $1960 .^{62}$

Part of the return to education involves a greater ability to migrate to places with higher income potential. Iowa was not only a net exporter of educated labor, but a significant portion of the returns to education for Iowaborn males in 1939 accrued through migration. ${ }^{63}$ This portion of the returns to education is not captured by our estimates. A key question in interpreting our estimated change in the returns to education from 1914 to 1939 is whether differential migration by education shifted over the period. Although no data are available to examine migration by education prior to the 1940 U.S. census, we can compare migration rates out of Iowa for Iowaborn males by occupation in 1910 and 1940 using the 1910 and 1940 IPUMS. The rate of migration out of Iowa for Iowa-born males (aged 18 to 65 ) in nonfarm occupations was similar in the two years: 47 percent remained in Iowa in 1910 and 50 percent remained in Iowa in 1940. Differential rates of migration by occupation (a reasonable proxy for educational attainment) were also similar in the two years. Thus, the returns to schooling for Iowa residents in 1914 and 1939 reported in Table 8 are likely to be an

\footnotetext{
${ }^{62}$ The decline in education returns in Iowa is consistent with the sharp reduction in the white-collar wage premium nationwide from 1914 to 1939 and also with its further collapse in the 1940s. See Goldin and Katz, "Decline" and "Returns."

${ }^{63}$ Using the 1940 IPUMS we find that mean years of schooling for adult male, full-year, nonfarm workers (18- to 65- years old) born in Iowa who migrated to another state was 10.9 years but was 10.4 years for those born in lowa who did not migrate. The coefficient on years of schooling from a standard $\log$ annual earnings regressions (for full-year, nonfarm male workers in 1939, including a quartic in experience and a race dummy) is 0.088 for those born in Iowa (regardless of current state of residence), but 0.066 for the lowa-born currently residing in lowa.
} 


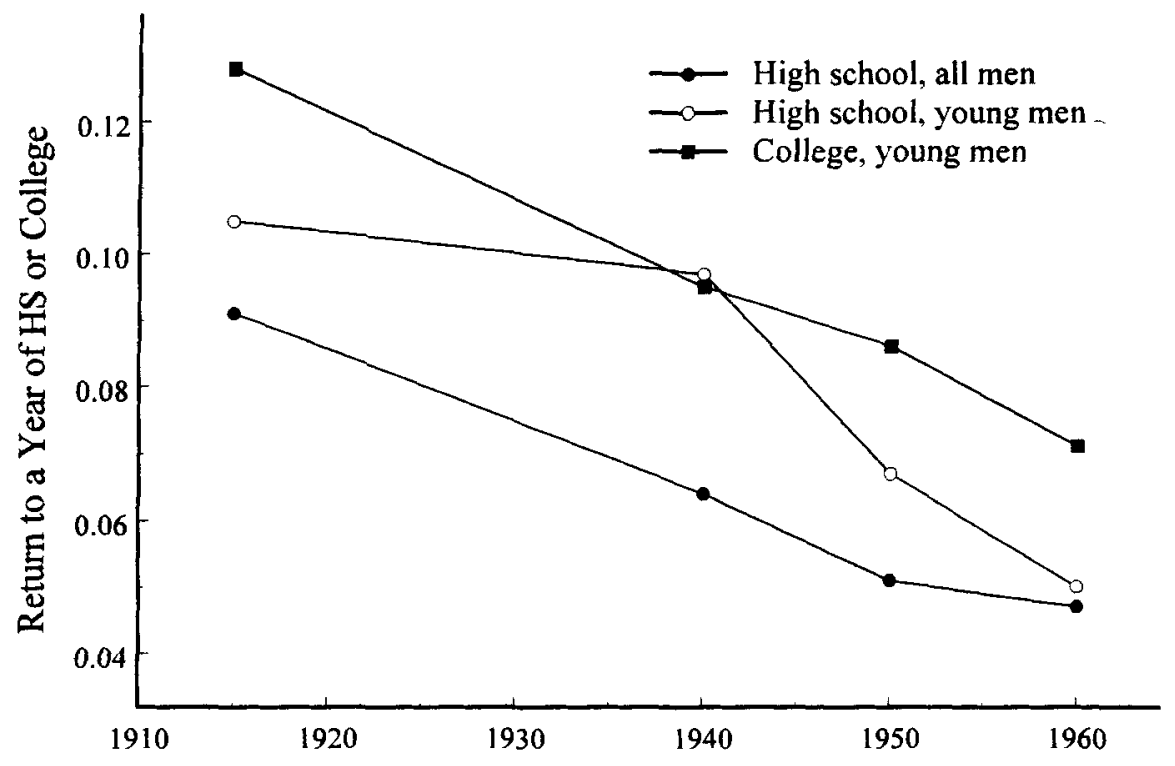

FIGURE 2

RETURNS TO HIGH SCHOOL AND COLLEGE, IOWA 1915 TO 1960

Source: Table 8, rows 1, 2, 3, and 7 for high school returns of all men and young men and for college returns for young men.

underestimate of the total returns to education for the Iowa-born, but the change in the returns to education over time will likely be unaffected since the rate of differential out-of-state migration by the more-educated was similar for both years.

An important caveat to our findings concerns unemployment. The summary data in Table 8 exclude, for each of the census years, those who worked fewer than 50 weeks. But education reduced the probability of unemployment and some of its return came through that route. When unemployment is relatively low, as was the case in 1914 and 1949, the effect of schooling in reducing unemployment increases the return to a year of schooling by only about 1 percentage point (see Appendix Table A3). But in 1939 when unemployment was 17.2 percent nationwide, the premium to a year of schooling from reducing unemployment was between 4 and 5 percentage points or about a 60 percent increase.$^{64}$ Educational returns were greater in 1914 than in 1939 among fullyear workers. But the reverse holds when all workers experiencing unemployment over the year are included. Their inclusion, however, is not entirely justified since the unemployment risk was substantially greater in 1939 than in 1914.

${ }^{64}$ Nationwide the unemployment rate was 7.9 percent in $1914,5.9$ percent in 1949 , and 5.5 percent in 1959 (U.S. Bureau of the Census, Historical Statistics, series D 85). 
One may wonder whether the large increase in high school-educated youths from 1915 to 1960 led to a decline in their intrinsic ability and whether the increase in secondary-school enrollments was accompanied by a decrease in educational performance. If so, the decline in the returns to education from 1915 to 1960 would come from differential selection or from reduced quality of education.

An exhaustive compilation of almost 30 separate large-scale studies of IQ test scores of high school students finds that, rather than declining, test scores increased from 1917 to $1942 .{ }^{65}$ The increase should not be surprising since many rural youths who were not attending high school in the 1910s lived a considerable distance from the nearest school and many urban youths who were not in school were the children of recent immigrants. These teenagers were less constrained by ability than they were by circumstance. Evidence on achievement can be found in the history of the famed Iowa Test of Educational Development. Grades on the Iowa tests rose from the early 1940 s, when the test became statewide, to the late $1960 \mathrm{~s} .{ }^{66}$ The evidence just cited suggests that the decrease in the rate of return to years of schooling was not caused by a decline in the ability of those who attended public high schools. Nor was it caused by a diminution in the content of high school education. Furthermore, among high school graduates continuing to college there was far less selectivity, as measured by cognitive test scores, in the 1920s than in the 1930s and $1940 \mathrm{~s} .{ }^{67}$ Thus we suspect that there is less upward ability bias in estimates of returns to college in 1915 than for the 1940 to 1960 period, and probably no greater bias for high school returns in 1915 than for the later period. Therefore the decline in the rate of return to education from 1915 to 1940 is unlikely to be an artifact of a change in ability bias.

A related issue is whether our estimates can be interpreted as reflecting the causal effect of schooling on earnings rather than the effect of unmeasured ability differences among individuals with varying amounts of schooling. Individuals from Iowa's more elite families, for example, were more likely to attend high school and college and thus the estimated schooling effects could partially reflect the correlation of schooling with other labor-market advantages. We find (as shown in Appendix Table A2) that the addition of controls for family background (such as church affiliation, national origin, and parental nativity) has almost no impact on the return estimates. The children of wealthier and more-educated parents were more likely to attend high school, but the vast majority of those attending Iowa's secondary schools in 1914 were from families that were not headed

\footnotetext{
${ }^{65}$ See Bishop, "Is the Test Score Decline," for the original citations.

${ }^{66}$ Ibid., figure 1.

${ }^{67}$ Taubman and Wales, Mental Ability.
} 
by a high school graduate nor an individual in a white-collar job. ${ }^{68}$ Recent studies using plausibly exogenous sources of variation in schooling find larger "causal" effects on earnings than those implied by OLS cross-section estimates, for marginal workers affected by improved access to schooling. ${ }^{69}$ Although we cannot rule out the possibility that ability bias afflicts the 1915 results, the literature using more recent data, as well as the evidence that there was less sorting across education levels by cognitive test scores in the earlier period, suggest that the overall bias may be modest.

\section{CONCLUDING REMARKS}

We have used a unique dataset - the 1915 Iowa State Census - to estimate the returns to schooling on the eve of the "high school movement," the greatest transformation in the history of American education. We find substantial returns to a year of high school (and college)-on the order of 11 percent - and a large impact of secondary schooling on earnings even for bluecollar workers and farmers. Across all male workers, about half of the return to secondary school and college was gained within the sector or occupation; for those in white-collar occupations, almost all was garnered within occupations. Our finding on the premium to education for farmers is buttressed by an analysis of agricultural productivity by county for 1915 and 1925 . In counties having a greater fraction of adults who had attended high school or college, agricultural productivity was markedly higher.

Comparisons with census data for Iowa in 1940, 1950, and 1960 reveal greater returns to years of schooling in 1915 with some qualifications due to substantial unemployment in 1940 and measurement issues regarding selfemployment. Our estimate of the decrease in the return to years of education from 1915 to 1940 reinforces previous findings on wage ratios for occupations having different educational requirements. ${ }^{70}$ We conclude from all these pieces of evidence that the return to education decreased sometime between 1915 and 1940 and then again during the "Great Compression" of the 1940s.

Given the substantial pecuniary returns to secondary and higher education in 1915 and their widespread nature across diverse sectors and occupations,

${ }^{68}$ Goldin and Katz, "Human Capital."

${ }^{69}$ Such sources of variation have included changes in compulsory schooling laws, interactions of compulsory schooling laws with quarter of birth, and geographic proximity to college. See Card, "Causal Effect of Education," for a careful survey of this literature.

${ }^{70}$ We have constructed a national time series for the earnings of "ordinary" white-collar workers (such as clerks, typists, stenographers, bookkeepers) by sex and occupation for 1895 to 1940 . Relative to production workers in manufacturing, we find a marked decrease in the ratio around the late 1910s to early 1920s that remained in place for some time. These trends also hold for college professors, engineers, and many blue-collar crafts, such as machinists and skilled printing tradesmen. See Goldin and Katz, "Decline" and "Returns." 
it is no wonder that the high school movement took root at that moment in American history. With the increase in secondary schooling that swept the nation beginning around 1910, education narrowed the gap in its great "race" with technology. Technology advanced rapidly, but education appears to have been ahead at the halfway point of the twentieth century. ${ }^{71}$ More recently, however, the lead appears to have been lost and technology may have won the race at century's end.

${ }^{11}$ Other factors that may have played an important role in the narrowing of the U.S. wage structure in the first half of the twentieth century include the curtailment of immigration beginning in the 1910s and the rising importance of labor unions especially in the mid-1930s.

\section{Data Appendix: The 1915 Iowa State Census Sample}

The 1915 State Census of Iowa is a unique document. It is the first census, state or federal, to include information on education and income prior to the U.S. federal census of 1940 , and it contains considerable detail on other aspects of individuals and households some of which were never asked in a U.S. census. The Iowa state census of 1915 is a complete sample of the residents of the state. The returns were written by census takers (assessors) on index cards, one for each individual. These cards were kept in the Iowa State archives in Des Moines and were microfilmed in 1986 by the Genealogical Society of Salt Lake City.

The census cards, see Appendix Figure 1, were sorted by county, although large cities (those having more than 25,000 residents) are grouped separately. Within each county or large city, records were alphabetized by last name and within last name by first name. Our project sampled the records for three of the largest Iowa cities (Davenport, Des Moines, Dubuque) and for ten counties that did not contain a large city. The ten counties were chosen from the 99 lowa counties randomly within four education groupings. The "rural"counties span the geography of the state: Clay and Lyon in the northwest, Mitchell in the north central, Johnson and Buchanan in the east central, Marshall in the central, Wayne in the south central, Adair and Montgomery in the southwest, and Carroll in the west central.

All of the tabulations use sampling weights to reflect the differing sampling rates in the urban and rural samples. The weighted tabulations are intended to be representative of the entire state of lowa (except for individuals in the rural areas of counties containing large cities). Our "urban" sample contains 26,768 observations or 5.5 percent of Iowa's population in large cities, and the "rural sample" contains 33,305 observations or 1.8 percent of the population in counties without large cities.

All variables on the census cards were recorded. These include (in their order on the card): card number, sex, color, marital status, months of schooling in 1914 by type of school (public elementary, private elementary, high school, college), whether individual could read and/or write, whether handicapped (blind, insane, deaf, idiot), if foreign born whether naturalized, years in Iowa and years in the United States, full name, age, address (county, post office, town or township, ward), occupation, months unemployed and total earnings from occupation for 1914, extent of education (years in common, grammar, high school, college), birthplace, whether person owned home or farm, incumbrance on and value of the same, military service, church affiliation, father's and mother's birthplaces, the assessor's name, and remarks. 


\begin{tabular}{|c|c|}
\hline Card No. .................. & 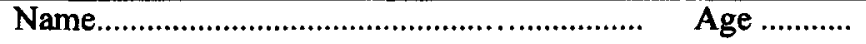 \\
\hline Sex: Male Female & County \\
\hline Color ...................... & 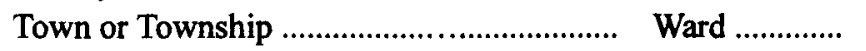 \\
\hline Marital Status ..... & Occupation ..................... Months in 1914 Unemployed ......... \\
\hline Months Schl. 1914 & 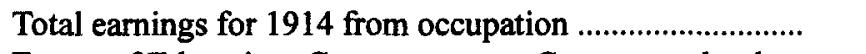 \\
\hline $\begin{array}{l}\text { Public ... High.... } \\
\text { Private...College... }\end{array}$ & $\begin{array}{l}\text { Extent of Education: Common ... yrs. Grammar school ... yrs. } \\
\text { High school .... yrs. College.... yrs. }\end{array}$ \\
\hline $\begin{array}{l}\text { Read .............. } \\
\text { Write ............ }\end{array}$ & $\begin{array}{l}\text { Birthplace ......... Do you own your home or farm? yes no } \\
\text { Incumbrance on farm, home } \$ . . . . . \text { Value of farm, home } \$ \ldots\end{array}$ \\
\hline $\begin{array}{l}\text { Blind ... Deaf ... } \\
\text { Insane ... Idiot ... }\end{array}$ & $\begin{array}{l}\text { Milit. Service: Civil War .. Mexican .. Spanish .. Infantry.. } \\
\text { Cavalry .. Artillery .. Navy .. State .. Regiment .. Company .. }\end{array}$ \\
\hline If Foreign Born & Church Affiliation \\
\hline Naturalized? .... & Father's Birthplace .............. Mother's Birthplace ................ \\
\hline Yrs IA... Yrs US... & Remarks ................................... Signed ............. Assessor \\
\hline
\end{tabular}

APPENDIX FIGURE 1

FACSIMILE CENSUS CARD

APPENDIX TABLE Al

RETURNS TO EDUCATION FOR DIFFERENT SUB-SAMPLES: 18- TO 65-YEAR OLD MALES, ALL OCCUPATIONS, IOWA 1915

\begin{tabular}{|c|c|c|c|c|c|}
\hline & $\begin{array}{l}\text { (1) } \\
\text { All }\end{array}$ & $\begin{array}{c}\text { (2) } \\
\text { White, } \\
\text { Native-Born }\end{array}$ & $\begin{array}{l}(3) \\
\text { Foreign- } \\
\text { Born }\end{array}$ & $\begin{array}{c}\text { (4) } \\
\text { Urban }\end{array}$ & Rural \\
\hline Common school, years & $\begin{array}{c}0.0427 \\
(0.00269)\end{array}$ & $\begin{array}{c}0.0420 \\
(0.00304)\end{array}$ & $\begin{array}{c}0.0525 \\
(0.00607)\end{array}$ & $\begin{array}{c}0.0602 \\
(0.00397)\end{array}$ & $\begin{array}{c}0.0411 \\
(0.00383)\end{array}$ \\
\hline Grammar school, years & $\begin{array}{c}0.0533 \\
(0.00292)\end{array}$ & $\begin{array}{c}0.0548 \\
(0.00331)\end{array}$ & $\begin{array}{c}0.0491 \\
(0.00662)\end{array}$ & $\begin{array}{c}0.0677 \\
(0.00374)\end{array}$ & $\begin{array}{c}0.0412 \\
(0.00448)\end{array}$ \\
\hline High school, years & $\begin{array}{l}0.103 \\
(0.00448)\end{array}$ & $\begin{array}{l}0.107 \\
(0.00471)\end{array}$ & $\begin{array}{c}0.0538 \\
(0.0151)\end{array}$ & $\begin{array}{l}0.120 \\
(0.00468)\end{array}$ & $\begin{array}{l}0.103 \\
(0.00703)\end{array}$ \\
\hline College, years & $\begin{array}{l}0.103 \\
(0.00604)\end{array}$ & $\begin{array}{l}0.113 \\
(0.00656)\end{array}$ & $\begin{array}{c}0.0644 \\
(0.0162)\end{array}$ & $\begin{array}{l}0.106 \\
(0.00609)\end{array}$ & $\begin{array}{c}0.0986 \\
(0.00951)\end{array}$ \\
\hline Business school, dummy & $\begin{array}{c}0.379 \\
(0.0850)\end{array}$ & $\begin{array}{c}0.383 \\
(0.0874)\end{array}$ & $\begin{array}{c}0.184 \\
(0.366)\end{array}$ & $\begin{array}{c}0.277 \\
(0.0499)\end{array}$ & $\begin{array}{c}0.169 \\
(0.466)\end{array}$ \\
\hline Native-born & $\begin{array}{c}0.222 \\
(0.0252)\end{array}$ & & & $\begin{array}{l}0.148 \\
(0.0271)\end{array}$ & $\begin{array}{c}0.272 \\
(0.0395)\end{array}$ \\
\hline $\begin{array}{l}\left.\text { (Years in U.S. } \times 10^{-2}\right) \times \\
\text { foreign-born }\end{array}$ & $\begin{array}{c}0.677 \\
(0.0922)\end{array}$ & & & $\begin{array}{c}0.228 \\
(0.0993)\end{array}$ & $\begin{array}{c}0.912 \\
(0.145)\end{array}$ \\
\hline White & $\begin{array}{c}0.208 \\
(0.0550)\end{array}$ & & & $\begin{array}{c}0.248 \\
(0.0354)\end{array}$ & $\begin{array}{c}0.139 \\
(0.165)\end{array}$ \\
\hline Experience & $\begin{array}{l}0.123 \\
(0.00819)\end{array}$ & $\begin{array}{l}0.124 \\
(0.00875)\end{array}$ & $\begin{array}{l}0.128 \\
(0.0282)\end{array}$ & $\begin{array}{c}0.123 \\
(0.00870)\end{array}$ & $\begin{array}{l}0.127 \\
(0.0126)\end{array}$ \\
\hline Experience $^{2}$ & $\begin{array}{l}-0.00544 \\
(0.000654)\end{array}$ & $\begin{array}{l}-0.00557 \\
(0.000714)\end{array}$ & $\begin{array}{c}-0.00573 \\
(0.00200)\end{array}$ & $\begin{array}{l}-0.00624 \\
(0.000705)\end{array}$ & $\begin{array}{c}-0.00543 \\
(0.00100)\end{array}$ \\
\hline Experience $^{3} \times 10^{-2}$ & $\begin{array}{l}0.0116 \\
(0.00199)\end{array}$ & $\begin{array}{l}0.0121 \\
(0.00221)\end{array}$ & $\begin{array}{l}0.0115 \\
(0.00557)\end{array}$ & $\begin{array}{c}0.0143 \\
(0.00217)\end{array}$ & $\begin{array}{c}0.0114 \\
(0.00303)\end{array}$ \\
\hline Experience $\times 10^{-4}$ & $\begin{array}{l}-0.00995 \\
(0.00202)\end{array}$ & $\begin{array}{l}-0.0105 \\
(0.00227)\end{array}$ & $\begin{array}{l}-0.00933 \\
(0.00528)\end{array}$ & $\begin{array}{l}-0.0124 \\
(0.00222)\end{array}$ & $\begin{array}{c}-0.00984 \\
(0.00307)\end{array}$ \\
\hline$R^{2}$ & 0.199 & 0.207 & 0.174 & 0.286 & 0.187 \\
\hline SEE & 0.624 & 0.619 & 0.648 & 0.494 & 0.659 \\
\hline Number of observations & 14,699 & 11,895 & 2,583 & 7,590 & 7,109 \\
\hline
\end{tabular}


APPENDIX TABLE A1 - continued

Notes: The dependent variable is $\log$ (annual earnings). A dummy variable indicating that "years in the United States" is missing is included in columns 1, 4, and 5 . All regressions are weighted by urban and rural sampling weights (see the Data Appendix for weighting information). Standard errors are in parentheses. See also the notes to Table 4.

Source: Iowa 1915 Sample (see the Data Appendix).

APPENDIX TABLE A2

SENSITIVITY OF RETURNS TO EDUCATION ESTIMATES TO ALTERNATIVE CONTROL VARIABLES: 18- TO 65-YEAR OLD MALES, ALL OCCUPATIONS, IOWA 1915

Log (Annual Earnings)

\begin{tabular}{|c|c|c|c|c|}
\hline & \multicolumn{4}{|c|}{ Log (Annual Earnings) } \\
\hline & (1) & (2) & (3) & (4) \\
\hline Common school, years & $\begin{array}{c}0.0427 \\
(0.00269)\end{array}$ & $\begin{array}{c}0.0320 \\
(0.00250)\end{array}$ & $\begin{array}{c}0.0405 \\
(0.00271)\end{array}$ & $\begin{array}{c}0.0357 \\
(0.00264)\end{array}$ \\
\hline Grammar school, years & $\begin{array}{c}0.0533 \\
(0.00292)\end{array}$ & $\begin{array}{c}0.0462 \\
(0.00271)\end{array}$ & $\begin{array}{c}0.0446 \\
(0.00299)\end{array}$ & $\begin{array}{c}0.0404 \\
(0.00292)\end{array}$ \\
\hline High school, years & $\begin{array}{l}0.103 \\
(0.00448)\end{array}$ & $\begin{array}{c}0.0846 \\
(0.00417)\end{array}$ & $\begin{array}{l}0.104 \\
(0.00454)\end{array}$ & $\begin{array}{c}0.0953 \\
(0.00443)\end{array}$ \\
\hline College, years & $\begin{array}{l}0.103 \\
(0.00604)\end{array}$ & $\begin{array}{c}0.0972 \\
(0.00559)\end{array}$ & $\begin{array}{c}0.0989 \\
(0.00601)\end{array}$ & $\begin{array}{c}0.0919 \\
(0.00585)\end{array}$ \\
\hline Business school, dummy & $\begin{array}{c}0.379 \\
(0.0850)\end{array}$ & $\begin{array}{c}0.327 \\
(0.0796)\end{array}$ & $\begin{array}{c}0.295 \\
(0.0846)\end{array}$ & $\begin{array}{c}0.282 \\
(0.0824)\end{array}$ \\
\hline Native born & $\begin{array}{c}0.222 \\
(0.0252)\end{array}$ & $\begin{array}{c}0.171 \\
(0.0234)\end{array}$ & $\begin{array}{c}0.211 \\
(0.0314)\end{array}$ & $\begin{array}{c}0.192 \\
(0.0306)\end{array}$ \\
\hline $\begin{array}{l}\left.\text { (Years in U.S. } \times 10^{-2}\right) \times \\
\text { foreign-born }\end{array}$ & $\begin{array}{c}0.677 \\
(0.0922)\end{array}$ & $\begin{array}{c}0.477 \\
(0.0857)\end{array}$ & $\begin{array}{c}0.565 \\
(0.0982)\end{array}$ & $\begin{array}{c}0.404 \\
(0.0958)\end{array}$ \\
\hline White & $\begin{array}{l}0.208 \\
(0.0550)\end{array}$ & $\begin{array}{l}0.161 \\
(0.0508)\end{array}$ & $\begin{array}{l}0.205 \\
(0.0556)\end{array}$ & $\begin{array}{c}0.189 \\
(0.0541)\end{array}$ \\
\hline Experience & $\begin{array}{l}0.123 \\
(0.00819)\end{array}$ & $\begin{array}{l}0.108 \\
(0.00759)\end{array}$ & $\begin{array}{l}0.122 \\
(0.00814)\end{array}$ & $\begin{array}{l}0.0869 \\
(0.00806)\end{array}$ \\
\hline Experience $^{2}$ & $\begin{array}{l}-0.00544 \\
(0.000654)\end{array}$ & $\begin{array}{l}-0.00474 \\
(0.000606)\end{array}$ & $\begin{array}{l}-0.00890 \\
(0.000650)\end{array}$ & $\begin{array}{l}-0.00423 \\
(0.000634)\end{array}$ \\
\hline Experience $^{3} \times 10^{-2}$ & $\begin{array}{c}0.0116 \\
(0.00199)\end{array}$ & $\begin{array}{c}0.0102 \\
(0.00184)\end{array}$ & $\begin{array}{c}0.0121 \\
(0.00197)\end{array}$ & $\begin{array}{c}0.00978 \\
(0.00192)\end{array}$ \\
\hline Experience ${ }^{4} \times 10^{-4}$ & $\begin{array}{l}-0.00995 \\
(0.00202)\end{array}$ & $\begin{array}{c}-0.00876 \\
(0.00187)\end{array}$ & $\begin{array}{l}-0.0104 \\
(0.00200)\end{array}$ & $\begin{array}{l}-0.00892 \\
(0.00195)\end{array}$ \\
\hline Months unemployed & & $\begin{array}{l}-0.132 \\
(0.00232)\end{array}$ & & \\
\hline Religious affiliation & & & & \\
\hline Jewish & & & $\begin{array}{c}0.403 \\
(0.770)\end{array}$ & $\begin{array}{c}0.352 \\
(0.0750)\end{array}$ \\
\hline Catholic & & & $\begin{array}{c}-0.00495 \\
(0.0155)\end{array}$ & $\begin{array}{c}0.00926 \\
(0.0151)\end{array}$ \\
\hline Lutheran & & & $\begin{array}{c}0.0378 \\
(0.0203)\end{array}$ & $\begin{array}{c}0.307 \\
(0.0198)\end{array}$ \\
\hline New England Protestant & & & $\begin{array}{c}0.105 \\
(0.0243)\end{array}$ & $\begin{array}{c}0.0820 \\
(0.0236)\end{array}$ \\
\hline Congregational & & & $\begin{array}{c}0.0731 \\
(0.0367)\end{array}$ & $\begin{array}{c}0.0437 \\
(0.0358)\end{array}$ \\
\hline Methodist & & & $\begin{array}{c}0.0961 \\
(0.0193)\end{array}$ & $\begin{array}{c}0.0638 \\
(0.0188)\end{array}$ \\
\hline
\end{tabular}


APPENDIX TABLE A2 - continued

\begin{tabular}{lcccc}
\hline \hline & \multicolumn{4}{c}{ Log (Annual Earnings) } \\
\cline { 2 - 5 } & $(1)$ & $(2)$ & $(3)$ & $(4)$ \\
\hline Baptist & & & 0.00661 & -0.0348 \\
& & & $(0.0326)$ & $(0.0318)$ \\
Other religious affiliation & & 0.105 & 0.0728 \\
Years in Iowa $\times 10^{-2}$ & & & $0.0189)$ & $(0.0184)$ \\
& & & 0.317 & 0.306 \\
Urban & & & $0.0481)$ & $(0.0468)$ \\
& & & 0.128 & 0.130 \\
Married & & & $0.0137)$ & $(0.0133)$ \\
& & & & 0.343 \\
Parents' nativity (10 & no & & & $(0.0121)$ \\
dummies) & & & yes & yes \\
$R^{2}$ & 0.199 & 0.316 & 0.213 & 0.254 \\
SEE & 0.624 & 0.577 & 0.619 & 0.603 \\
Number of observations & 14,699 & 14,639 & 14,699 & 14,699 \\
\hline
\end{tabular}

Notes: The dependent variable is $\log$ (annual earnings). The omitted religion in columns 3 and 4 is "religion not listed." A dummy variable indicating whether "years in the United States" was missing is included in all columns; columns 3 and 4 also include whether "years in Iowa" was missing, column 4 includes whether marital status was omitted. All regressions are weighted by urban and rural sampling weights (see the Data Appendix for weighting information). Standard errors are in parentheses. See also the notes to Table 4.

Source: Iowa 1915 Sample (see the Data Appendix). 


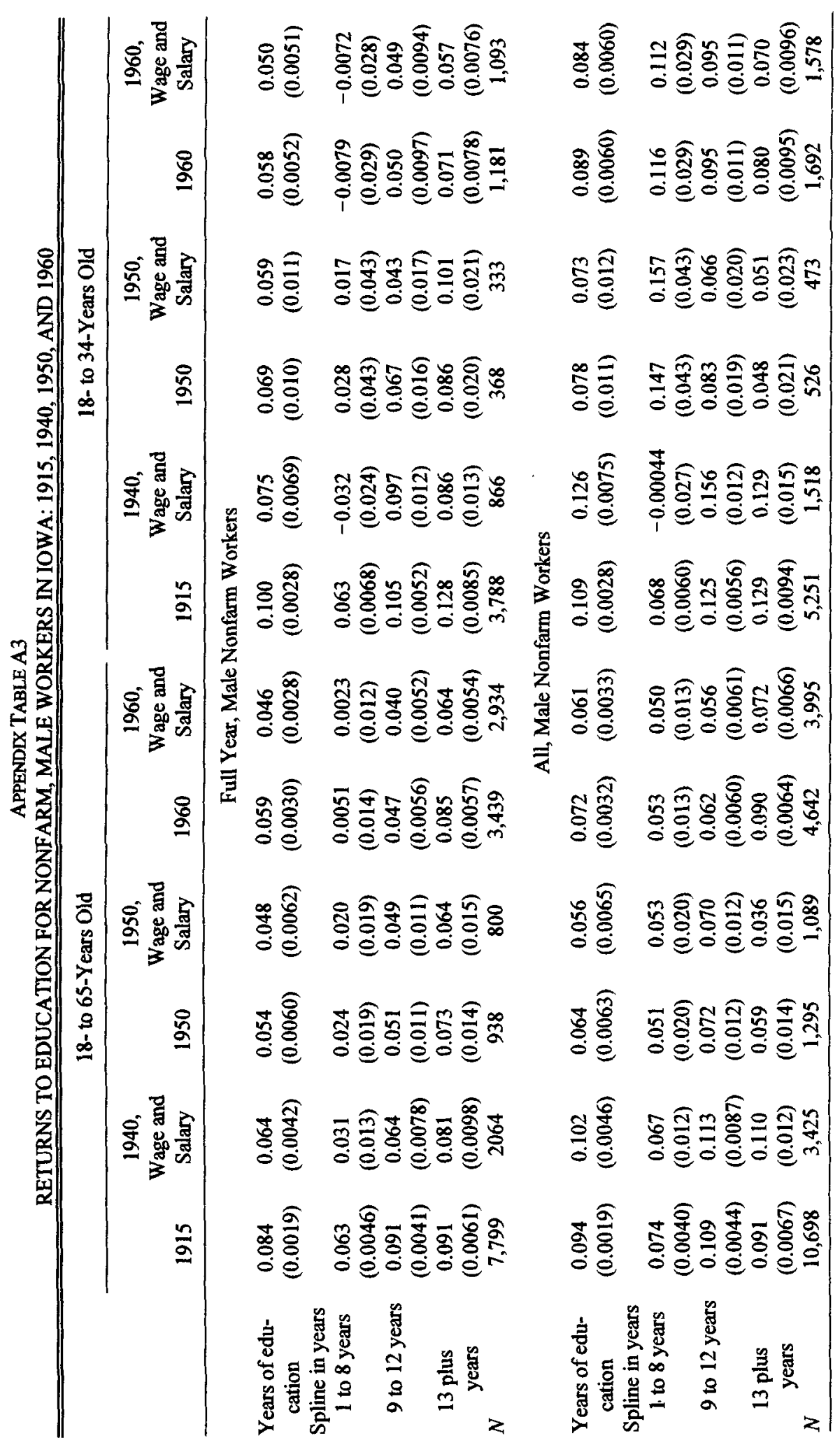


APPENDIX TABLE A3 - continued

Notes: Coefficients for "years of education" are from a regression of $(\mathrm{log})$ annual earnings on all years of education. In the 1940, 1950, and 1960 censuses, years of education is given as "highest grade completed." In the 1915 Iowa State Census, years of education is the (adjusted) sum of common school, grammar school, high school, and college years to approximate the 1940 U.S. population census measure of highest grade completed (see version 1 definition, Table 1). Years of education are truncated (top-coded) at 17 years in all the regression samples. Coefficients for the "spline in years" are also from a regression of $(\mathrm{log})$ annual earnings. In 1940 and 1950 years in the various grades are inferred from "highest grade completed." In the 1915 Iowa State Census, years in each level are listed separately. "Full year" is defined for 1940, 1950, and 1960 as more than 49 weeks of work; in 1915 it is defined as listing no unemployment. Controls in all regressions are: quartic in potential experience, whether native born, and whether white. Potential experience in each sample is given by min(age - 15, age years of education -7). Each of the samples deletes the lowest 1 percent of earners. The samples for 1940, 1950, and 1960 include only those living in the state of Iowa. All regressions for 1915 are weighted by urban and rural sampling weights (see Goldin and Katz, "Returns," appendix for weighting information). Regressions for 1940 are weighted by the 1940 IPUMS sampling weights. Top-coded earnings in $1940(2 \$ 5,000), 1950(2 \$ 10,000)$, and $1960(2 \$ 25,000)$ are multiplied by 1.5 . Standard errors are in parentheses.

Sources: Iowa 1915 Sample; 1940, 1950, and 1960 IPUMS.

\section{BIBLIOGRAPHY}

Bishop, John H. "Is the Test Score Decline Responsible for the Productivity Growth Decline?" American Economic Review 79 (March 1989): 178-97.

Braatz, Jay, and Robert D. Putnam. "Families, Communities, and Education in America: Exploring the Evidence." Harvard University Working Paper, July 1997.

Card, David. "The Causal Effect of Education on Earnings." In The Handbook of Labor Economics. Vol. 3A, edited by O. Ashenfelter and D. Card, 1801-63. Amsterdam: North-Holland Press, 1999.

Chandler, Alfred. The Visible Hand: The Managerial Revolution in American Business. Cambridge, MA: Harvard University Press, 1977.

Dubester, Henry J. State Censuses: An Annotated Bibliography of Censuses of Population Taken after the Year 1790 by States and Territories of the United States. Washington, DC: GPO, 1948.

Goldin, Claudia. "America's Graduation from High School: The Evolution and Spread of Secondary Schooling in the Twentieth Century." This JOURNAL 58 (June 1998): 345-73. See this JOURNAL 58 (December 1998): 1118 for Table 3.

. "Education Statistics." In Historical Statistics of the United States, Millennial Edition, edited by S. Carter, R. Sutch, et al. New York: Cambridge University Press, forthcoming.

Goldin, Claudia, and Lawrence F. Katz. "The Decline of 'Non-Competing Groups': Changes in the Premium to Education, 1890 to 1940." NBER Working Paper, no. 5202, August 1995.

"Why the United States Led in Education: Lessons from Secondary School Expansion, 1910 to 1940." NBER Working Paper no. 6144, August 1997.

."The Origins of Technology-Skill Complementarity." Quarterly Journal of Economics 113 (August 1998): 693-732.

."Human Capital and Social Capital: The Rise of Secondary Schooling In America, 1910-1940." Journal of Interdisciplinary History 29 (Winter 1999): 683-723.

."The Returns to Skill in the United States across the Twentieth Century." NBER

Working Paper no. 7126, May 1999.

. "The Shaping of Higher Education: The Formative Years in the United States, 1890 to 1940." Journal of Economic Perspectives 13 (Winter 1999): 37-62. 
."Education and Income in the Early 20th Century: Evidence from the Prairies." NBER Working Paper No. 7217, July 1999.

Goldin, Claudia, and Robert A. Margo. "The Great Compression: The Wage Structure in the United States at Mid-Century." Quarterly Journal of Economics 107 (February 1992): 1-34.

Gorseline, Donald Eugene. The Effect of Schooling Upon Income. Bloomington: The Graduate Council of Indiana University, 1932.

Huffman, Wallace. "Human Capital: Education and Agriculture." In Handbook of Agricultural Economics, edited by G Rausser and B. Gardner. Amsterdam: North Holland Press, 2000, forthcoming.

Inter-university Consortium for Political and Social Research (ICPSR). Census of Population, 1940 [United States]: Public Use Microdata Sample (ICPSR 8236). Ann Arbor, MI: ICPSR, 1984.

Jensen, Richard, and Mark Friedberger. "Education and Social Structure: An Historical Study of Iowa, 1870-1930." Newberry Library working paper. Chicago, 1976.

Johnson, Keach. "The State of Elementary and Secondary Education in Iowa in 1900," The Annals of Iowa 49 (Summer/Fall 1987): 26-57.

Lazonick, William. Competitive Advantage on the Shop Floor. Cambridge, MA: Harvard University Press, 1990.

Lillard, Lee, James P. Smith, and Finis Welch. "What Do We Really Know about Wages? The Importance of Nonreporting and Census Imputation." Journal of Political Economy 94 (June 1986): 489-506.

Mincer, Jacob. Schooling, Experience, and Earnings. New York: Columbia University Press for the National Bureau of Economic Research, 1974.

Rotella, Elyce. From Home to Office: U.S. Women at Work, 1870-1930. Ann Arbor, MI: UMI Research Press, 1981.

Ryan, Bryce, and Neal Gross. "Acceptance and Diffusion of Hybrid Corn Seed in Two Iowa Communities." Research Bulletin \#372 Agricultural Experiment Station, Iowa State College of Agriculture and Mechanic Arts, Ames (January 1950).

Schultz, Theodore W. Transforming Traditional Agriculture. New Haven, CT: Yale University Press, 1964.

Smith, Daniel Scott. “"The Number and Quality of Children': Education and Marital Fertility in Early Twentieth-Century Iowa." Journal of Social History 30 (Winter 1996): 367-93.

State of Iowa. Biennial Report of the Department of Public Instruction for [year] to [year]. Des Moines: State Printer, [year]. . Department of Agriculture. Thirteenth Annual Iowa Year Book of Agriculture. Des Moines: R. Henderson, State Printer, 1912.

. Census of Iowa for the Year 1915. Des Moines: R. Henderson, state printer, 1916. . Census of Iowa for the Year 1925. Des Moines, IA: The State of Iowa, 1926.

Taubman, Paul, and Terrence Wales. Mental Ability and Higher Educational Attainment in the 20th Century. NBER Occasional Paper 118. New York: National Bureau of Economic Research, 1972.

Tinbergen, Jan. Income Differences: Recent Research. Amsterdam: North-Holland Publishing Co., 1975.

Tyack, David, and Elisabeth Hansot. Learning Together: A History of Coeducation in American Schools. New York: Russell Sage Press, 1990.

U.S. Bureau of the Census. Thirteenth Census of the United States, 1910. Vol. 1. Population. Washington, DC: GPO, 1913.

. Thirteenth Census of the United States, 1910. Vol. 6. Agriculture. Washington, DC: GPO, 1913. 
Thirteenth Census of the United States, 1910. Vol. 8. Manufactures, 1909, General Report and Analysis. Washington, DC: GPO, 1913.

Fourteenth Census of the United States, 1920. Vol. 6. Agriculture. Washington, DC: GPO, 1923.

Historical Statistics of the United States from Colonial Times to the Present. Washington, DC: GPO, 1975.

U.S. Census Office. Twelfth Census of the United States, 1900. Vol. 7. Manufacturers. Part 1: United States by Industries. Washington, DC: GPO, 1902.

U.S. Department of Commerce. Statistical Abstract of the United States, 1925. Washington, DC: GPO, 1926.

U.S. Department of Education, National Center for Education Statistics. 120 Years of American Education: A Statistical Portrait. Washington, DC: GPO, 1993.

Welch, Finis. "Education in Production." Journal of Political Economy 78 (Jan./Feb. 1970): 35-59. 